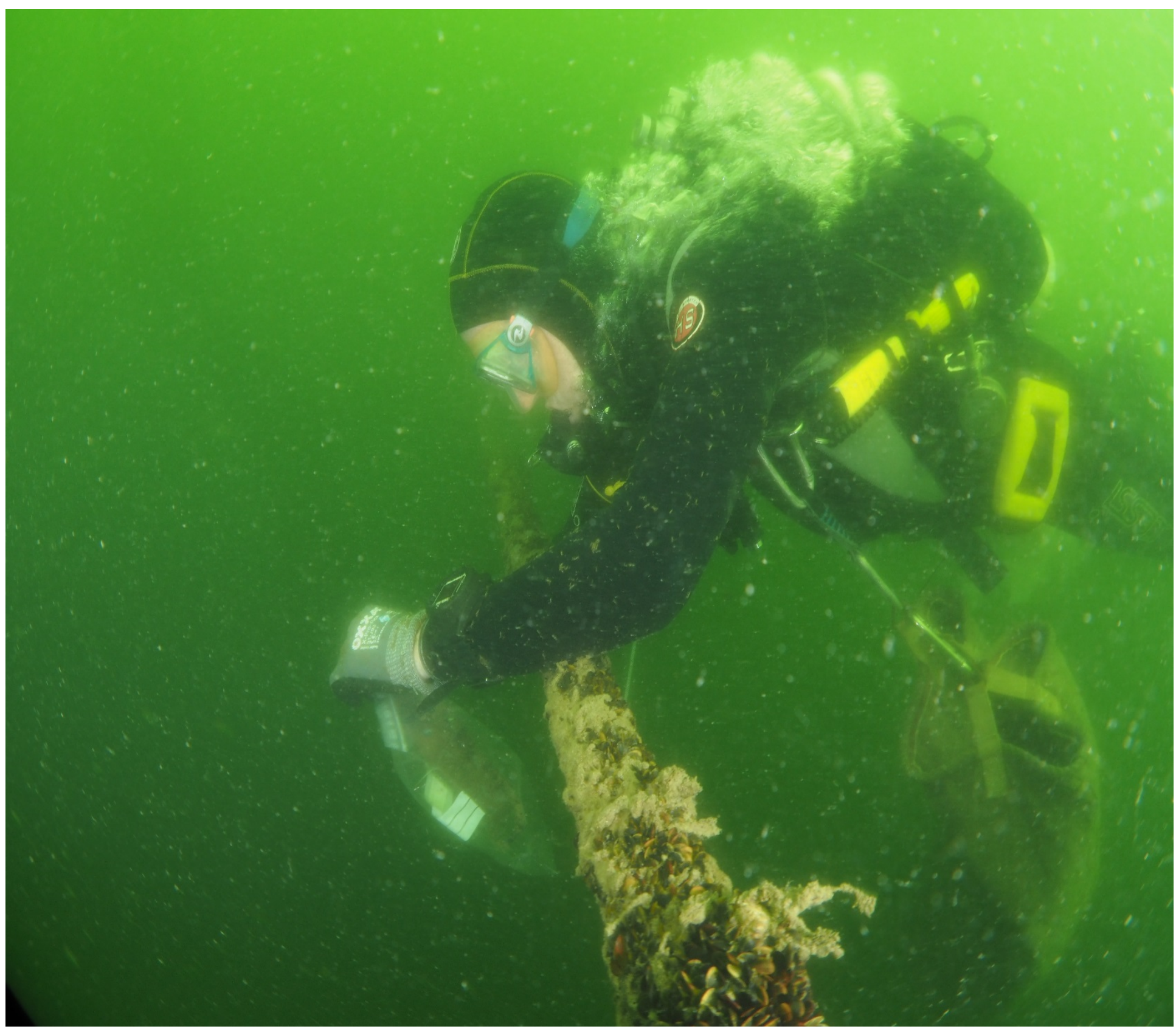

\title{
Biodiversity monitoring in seaweed farms by DNA metabarcoding using settlement plates and water samples
}

Author(s): M.S. Bernard ${ }^{1}$, L. Tonk ${ }^{1}$, G.A. de Groot ${ }^{2}$, S. Glorius ${ }^{1}$, H.M. Jansen ${ }^{1}$ 


\section{Biodiversity monitoring in seaweed farms by DNA metabarcoding using settlement plates and water samples}

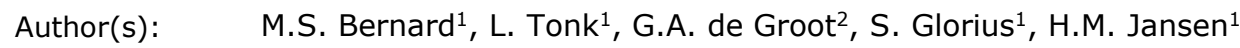

1 Wageningen Marine Research

2 Wageningen Environmental Research 
Keywords: environmental DNA, DNA metabarcoding, biodiversity, seaweed farming.

KB-24-002-041

This report can be downloaded for free from https://doi.org/10.18174/496237

Wageningen Marine Research provides no printed copies of reports.

Wageningen Marine Research is ISO 9001:2015 certified.

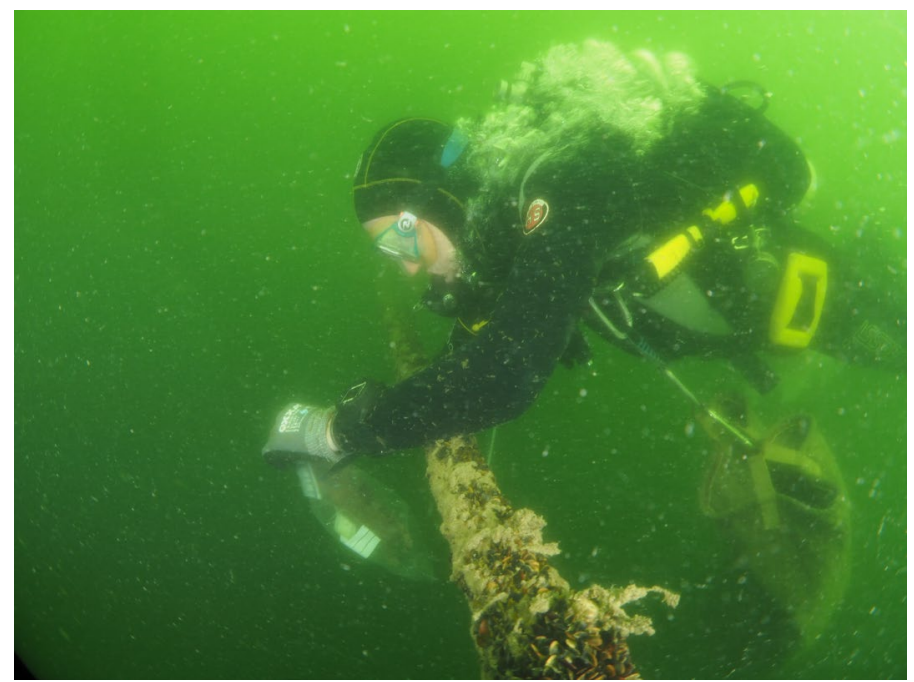

Photo cover: Oscar Bos

\section{(C) Wageningen Marine Research}

Wageningen Marine Research, an institute Wageningen Marine Research accepts no liability for consequential damage, nor within the legal entity Stichting for damage resulting from applications of the results of work or other data Wageningen Research (a foundation under obtained from Wageningen Marine Research. Client indemnifies Wageningen Dutch private law) represented by Dr. Marine Research from claims of third parties in connection with this application. M.C.Th. Scholten, Managing Director All rights reserved. No part of this publication may be reproduced and / or

KvK nr. 09098104, published, photocopied or used in any other way without the written permission WMR BTW nr. NL 8113.83.696.B16.

Code BIC/SWIFT address: RABONL2U IBAN code: NL 73 RABO 0373599285 


\section{Contents}

$\begin{array}{lr}\text { Summary } & 4\end{array}$

$\begin{array}{llr}1 & \text { Introduction } & 6\end{array}$

1.1 General introduction $\quad 6$

$\begin{array}{llr}1.2 & \text { Biodiversity in seaweed farms } & 6\end{array}$

$\begin{array}{lll}1.3 & \text { Biodiversity assessment } & 7\end{array}$

$\begin{array}{lll}1.4 & \text { Aims \& objectives of the study } & 8\end{array}$

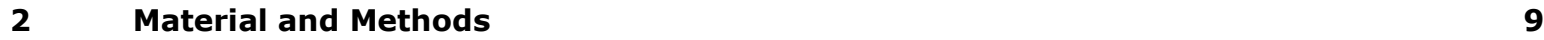

$\begin{array}{lll}2.1 & \text { Study sites } & 9\end{array}$

2.2 Flora and fauna on settlement plates from an offshore seaweed farm 9

2.3 eDNA analysis of water samples from an inshore seaweed farm 10

$\begin{array}{ll}2.4 & \text { DNA extraction and bioinformatic analysis } \\ \end{array}$

3 Results $\quad 12$

3.1 Biodiversity on settlement plates 12

$\begin{array}{lll}3.2 & \text { Biodiversity in water samples } & 14\end{array}$

$\begin{array}{ll}3.3 & \text { Detection of non-native species } \\ \end{array}$

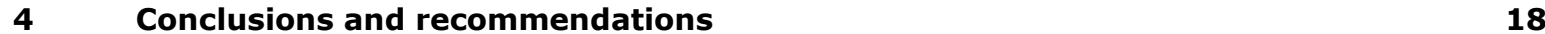

4.1 Suitability of DNA metabarcoding for biodiversity analyses in seaweed farms 18

4.2 Recommendation for the use of metabarcoding for biodiversity assessments in seaweed farms 


\section{Summary}

Large-scale offshore seaweed farming is foreseen in the Dutch North Sea in the future. In order to ensure a sustainable development of seaweed farming, it is essential to collect empirical data on the interaction of seaweed cultivation with marine ecosystems. In this study, we investigated methods to determine ecosystem services and impacts of seaweed farming on the basis of biodiversity, a key parameter for the functioning of ecosystems. Growing seaweed biomass and cultivation structures can serve as a refuge for fauna, nursery for fish and create new substratum for sessile organisms and thereby positively contributing to biodiversity. On the other hand, seaweed farming could also act as a stepping stone for non-native species or as a reservoir for diseases and pests. These processes are frequently described for seaweed farming, but empirical measurements are generally lacking.

Traditionally, the biodiversity on seaweeds is assessed morphologically with the help of identification keys and microscopes, but the recent advancement in high-throughput sequencing has opened ways for the use of molecular identification techniques in biodiversity assessments. In this study, the use of DNA metabarcoding for the analysis of the flora and fauna in seaweed farms was tested based on bulk samples from settlement plates deployed in an offshore seaweed farm in the North Sea to evaluate the number of sessile organisms attached to the farm structures. Furthermore, a preliminary trial was performed to assess whether mobile fauna, such as fish, can be detected via eDNA. Therefore, water samples were collected from an inshore seaweed farm in the Eastern Scheldt, where the presence of fish has been confirmed visually by video techniques.

The analysis of settlement plates resulted in an extensive list of detected sequences and a high number of identified taxa (134 taxa). A broad taxonomic coverage of 25 different divisions was reached. This indicates that seaweed farms indeed present a habitat with a high biodiversity. The use of DNA techniques does not currently allow quantification, and the most abundant species could therefore not be identified. However, visual observation from the settlement plates as well as the seaweed cultivation lines indicated that the farming structures were heavily fouled by the blue mussel (Mytilus edulis). This species was also detected by DNA metabarcoding with a high read abundance. The study was not designed to evaluate differences between control and farm sites, but no difference in species composition was observed between settlement plates located in areas with good seaweed growth compared to sites where seaweed growth was absent. It can therefore not (yet) be concluded whether the seaweed itself or the farming structures are responsible for this high species diversity. Out of the 134 taxa, two nonnative species were identified by a comparison with the species list of the Dutch North Sea (Nederlands Soortenregister): The bay barnacle (Amphibalanus improvisus) which is commonly found from the Atlantic and Gulf Coasts of North America to the European Atlantic and the Mediterranean (on six out of 21 settlement plates), and the tropical red alga Kappaphycus sp. of which no previous records exist from European waters (on one settlement plate). It is questionable whether the species can actually survive in the North Sea because it is a tropical species.

The analysis of environmental DNA in water samples also resulted in an extensive list of identified species (210 taxa, in 31 different divisions). Although the main reason to test this method was the assessment of fish DNA in the seawater, no fish species were detected and overall, the amount of mobile species detected in the seawater samples was low. Thus, further preliminary studies are necessary before DNA metabarcoding of water samples can be used for assessments of mobile fauna. A comparison of the species list with the Nederlands Soortenregister showed that 11 non-native species were detected in the water samples. These were, however, well-known exotic species for the Eastern Scheldt, such as the widely distributed soft shell calm (Ruditapes philippinarium, now also known as Venerupis philippinarum) and the Pacific oyster (Crassostrea gigas, now also known as Magallana gigas).

DNA metabarcoding has several advantages: it can be easily extended to large scale samplings and may be more precise for species which are difficult to identify based on their morphology, such as cryptic and rare species or juveniles. On the other hand, DNA metabarcoding depends strongly on the 
representation of species in reference databases and results may be biased by the marker choice. Furthermore, the interpretation of results can be difficult, for instance in the case of water samples where the origin of DNA is unclear. Fauna on settlement plates can readily be assessed by DNA metabarcoding, but the inclusion of baseline information $(t=0)$ and/or control sites, such as pelagic and nearby other hard structures, is crucial for the interpretability and reliability of collected data. The use of water samples, on the other hand, needs further investigation through preliminary studies before they can be recommended for biodiversity assessments.

Despite its limitations, DNA metabarcoding is a promising and powerful tool for biodiversity assessments if reference databases are expanded continuously and results are interpreted carefully. A list of recommendations for improving the use of metabarcoding for biodiversity assessments in seaweed farms is given at the end of the report. When fully developed, the tested methods will support the sustainable development of the Dutch seaweed sector. 


\section{Introduction}

\subsection{General introduction}

In the course of the Blue Growth agenda, the European Union supports the sustainable use and careful management of marine space as a source of energy and food. In this context, seaweed farming is often regarded as an environmentally friendly form of aquaculture with a high potential to cover the increasing protein demand of the world's population (Van denHoek and Bayoumi 2018). Large-scale offshore seaweed production is foreseen to take place in the Dutch North Sea where seaweeds could either be cultivated in stand-alone cultures or in multi-use settings with other maritime activities (van den Burg et al. 2013, Jansen et al. 2016). Seaweed does not only offer high nutritional value, but can also play a role in the mitigation of climate change through the conversion of $\mathrm{CO}_{2}$ to carbon-rich biomass (Hughes et al. 2012, Sondak et al. 2017). Furthermore, the growing seaweed biomass and cultivation structures can serve as a refuge for fauna, nursery for fish and create new substratum for sessile organisms (Wood et al. 2017). Seaweed farming can, however, also have negative impacts on the marine environment, especially when it is performed on a large scale (Wood et al. 2017, Campbell et al. 2019). For instance, extensive and dense cultivation of seaweeds can lead to local nutrient depletion which may cause competition between local species and the cultivated seaweed (Lüning and Pang 2003, Aldridge et al. 2012). Different methodologies have been suggested for offshore seaweed farming, including growing the seaweed on ropes on long lines, ladders, in grids or in ring-shaped designs (Buck and Buchholz 2004, Bak et al. 2018). It is, however, unclear whether these cultivation systems affect the environment differently.

In order to ensure a sustainable development of seaweed farming in Dutch offshore and coastal regions in the future, it is essential to collect empirical data on the interaction of seaweed cultivation with marine ecosystems. These data can then be used as a basis for realistic impact assessments. In this study, we investigated methods to determine ecosystem services and impacts of seaweed farming in the North Sea and the Eastern Scheldt on the basis of biodiversity, a key parameter for the proper functioning of ecosystems which is also part of the Marine Strategic Framework Directive of the European Commission (2008/56/EC).

\subsection{Biodiversity in seaweed farms}

Natural kelp forests are among the most diverse and productive ecosystems in the world (Steneck et al. 2002). Their three-dimensional structures support complex food webs and provide food, habitat and breeding areas for a variety of associated organisms (Bartsch et al. 2008, Christie et al. 2009). Seaweed beds usually occur on rocky substrate, providing a versatile habitat consisting of both soft and hard substrate which attracts a high number of different organisms. Consequently, seaweeds are colonized by a large number of benthic invertebrates, such as amphipods, bryozoans and gastropods (Nyberg et al. 2009, Leblanc et al. 2011, Walls et al. 2016), and a single kelp can host more than 7000 individuals (Jørgensen and Christie 2003). Additionally, seaweed beds also provide habitat for a high number of fish species (Bertocci et al. 2015, Wood et al. 2017).

While the biodiversity in natural seaweed populations has been well-studied over decades (Dayton 1985, Steneck et al. 2002), only few studies have addressed the biodiversity in seaweed farms (Walls et al. 2016, Wood et al. 2017). The hard substrate in seaweed farms is limited to the anchors and cultivation structures and seaweeds are usually suspended in the water column. Thus, the seaweed cultivated in farms may not be as easily accessible to benthic invertebrates as natural seaweed beds. However, planktonic larvae can settle on the seaweeds and develop into grazing juveniles (Wood et al. 2017). 
When Walls et al. (2016) compared the holdfasts of natural and cultivated Laminaria digitata, they found not only large differences in their morphology but also in the associated animals. While the overall numbers of individuals in the holdfasts were similar, higher species richness and a different species assemblage were found on the holdfasts of cultivated kelps (Walls et al. 2016). Previous studies also suggest that similarly to natural seaweed beds, seaweed farms serve as habitat for fish, especially for juveniles (Bergman et al. 2001, Zemke-White and Smith 2003, Tonk et al. 2019). On the other hand, seaweed farming can also act as a stepping stone for invasive species or as a reservoir for diseases and pests (Loureiro et al. 2015, Bernard 2018, Campbell et al. 2019). For instance, epiphytic algae are a major concern for seaweed aquaculture since they reduce yields and quality of the cultivated seaweed (Potin et al. 2002). Indeed, they are regularly observed in European seaweed cultures (Peteiro and Freire 2013, Walls et al. 2017). The reduced genetic diversity in seaweed farms makes them more susceptible to these threats than natural seaweed populations (Valero et al. 2017). But although diseases and pests pose a major concern for the global seaweed industry, to date they have rarely been studied in Europe (Loureiro et al. 2015).

Overall, surveys on the biodiversity in seaweed farms are still scarce. In order to assess the impact of seaweed farming on marine environments for a sustainable future development of the Dutch seaweed sector, reliable assessments and empirical data on the biodiversity in seaweed farms are needed.

\subsection{Biodiversity assessment}

Traditionally, the biodiversity present on seaweeds is assessed morphologically. All associated organisms are washed off from the host, preserved in ethanol or formalin and identified to the lowest possible taxonomic level based on their morphology with the help of identification keys and microscopes (James et al. 1986, Lippert et al. 2001, Christie et al. 2009, Nyberg et al. 2009). This technique does not only need highly trained staff but also has some other limitations. For instance, cryptic, small or especially rare species and juvenile life stages are difficult to identify based on morphological characteristics only (Leray and Knowlton 2015, Pavan-Kumar et al. 2015, Thomsen and Willerslev 2015).

In order to overcome these difficulties, traditional visual assessment can be combined with novel techniques. For instance, camera and video techniques are increasingly being used to assess mobile fauna in the marine environment (Pelletier et al. 2012, Tonk et al. 2019). Besides this, the use of molecular identification techniques has also increased due to the recent advancements in highthroughput sequencing techniques (Heather and Chain 2016).

DNA barcoding is an identification method that uses species-specific sequence variation at a fixed DNA fragment (the barcode region or marker region). This barcode region is present in all targeted taxa, but shows sufficient variation in nucleotide composition between taxa to be able to discriminate them. Identification of a specimen is performed by amplifying the barcode region from the DNA of this specimen using a universal primer set (i.e. primers matching all taxa that are encountered), determining the exact nucleotide code of the amplified fragment using sequencing, and comparing this code to a reference database containing representative codes of all taxa that are encountered. The term 'barcoding' refers to the unique barcodes on products bought in a shop, which allow product identification at the cash desk in a similar way.

DNA metabarcoding uses the same principle, but is able to identify the full list of taxa present in bulk or environmental samples (e.g. soil or water), instead of identifying a specimen of a single organism. Following DNA extraction from the entire sample, again a specific DNA fragment is amplified using a universal primer set, but here the resulting PCR product contains a mixture of different versions of this barcode fragment, due to the amplification of DNA from multiple taxa. A high-throughput sequencing method (next-generation sequencing or NGS) is applied to simultaneously determine the code of each of these thousands of fragments in the mixture. The resulting sequences are analysed and compared to public databases using bioinformatic pipelines (Rees et al. 2014, Pavan-Kumar et al. 2015). A schematic overview of this procedure is provided in Figure 1. 


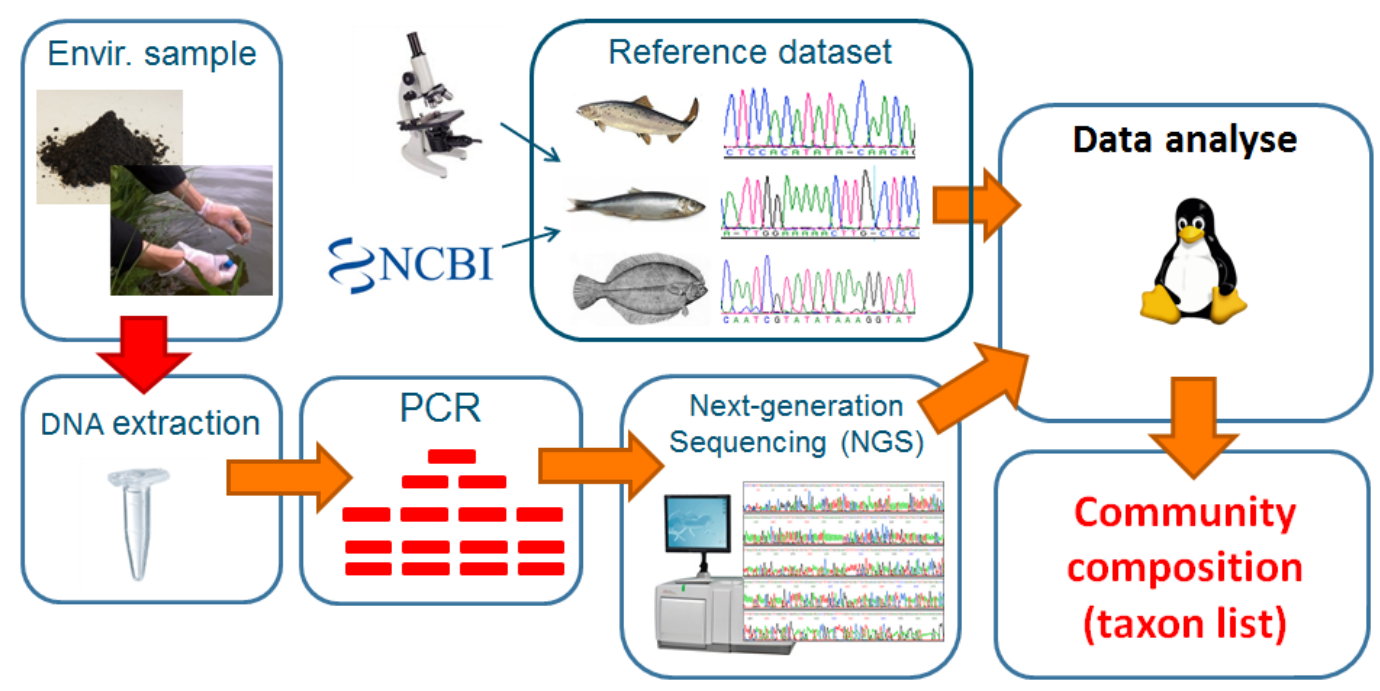

Figure 1 Overview of the DNA metabarcoding procedure.

In this study, the use of DNA metabarcoding for the analysis of the biodiversity in seaweed farms was tested based on bulk samples from settlement plates and environmental water samples:

Settlement plates. The use of settlement plates is a standardized method to investigate the establishment of sessile species on hard substrate (Mundy 2000, Nozawa et al. 2011, Slijkerman et al. 2017). A variety of materials, deployment methods, shapes and surfaces has been tested in the marine environment (see Nozawa et al. 2011). Species on settlement plates can be identified either based on morphological characters or by DNA metabarcoding.

Water samples. The analysis of water samples for biodiversity assessments is relatively new, but often regarded as a very promising technique that allows detection of mobile species (Valentini et al. 2016). Water contains environmental DNA (eDNA) which originates from defecation, urination, saliva or cells of organisms that are present somewhere in the water body (Rees et al. 2014). eDNA techniques can be efficient for revealing the presence of target species at low population densities and are easy to deploy at large spatial scales (Roussel et al. 2015).

\subsection{Aims \& objectives of the study}

1) Analysis of flora and fauna on settlement plates by DNA metabarcoding

2) Testing the applicability of DNA metabarcoding of water samples for the detection of flora and fauna, with focus on mobile (fish) species

3) Evaluation whether seaweed aquaculture may contribute to enhanced biodiversity in the seaweed farms (ecosystem service) or whether it poses a potential risk through the establishment of non-native species (environmental impact)

4) Assessment of the use of DNA metabarcoding of settlement plates and water samples for future monitoring and inventories.

The results presented in this study contribute to an improved estimation of the impact of seaweed aquaculture on the surrounding environment. This information is important for the aquaculture sector (Environmental Impact Assessments, EIAs) and policy makers, and will support the sustainable development of the Dutch seaweed sector in the future. 


\section{$2 \quad$ Material and Methods}

\section{$2.1 \quad$ Study sites}

\section{Offshore}

There is a growing interest in offshore seaweed cultivation in the Dutch North Sea. The North Sea Innovation lab (NSIL) is a test location for offshore seaweed farming where sugar kelp (Saccharina latissima) is grown on cultivation ropes on long lines. It is located $12 \mathrm{~km}$ off the coast of Den Haag (Scheveningen, Fig. 2, red pin). Settlement plates were deployed within NSIL to assess the sessile fauna in an offshore seaweed cultivation site.

\section{Inshore}

To assess mobile fauna, water samples were analysed by DNA metabarcoding. Only a few mobile species were expected to be attracted to the NSIL offshore test location due to the small spatial scale of the farm consisting of only one cultivation line. Therefore, water samples were taken in a larger inshore seaweed farm in the Eastern Scheldt (Seaweed Harvest Holland, Fig. 2, green dashed pin) instead to test the applicability of this method. At the production site in the Schelphoek, seaweed is cultivated year-round in long line cultivation with the green seaweed Ulva sp. growing during summer and $S$. latissima during winter.

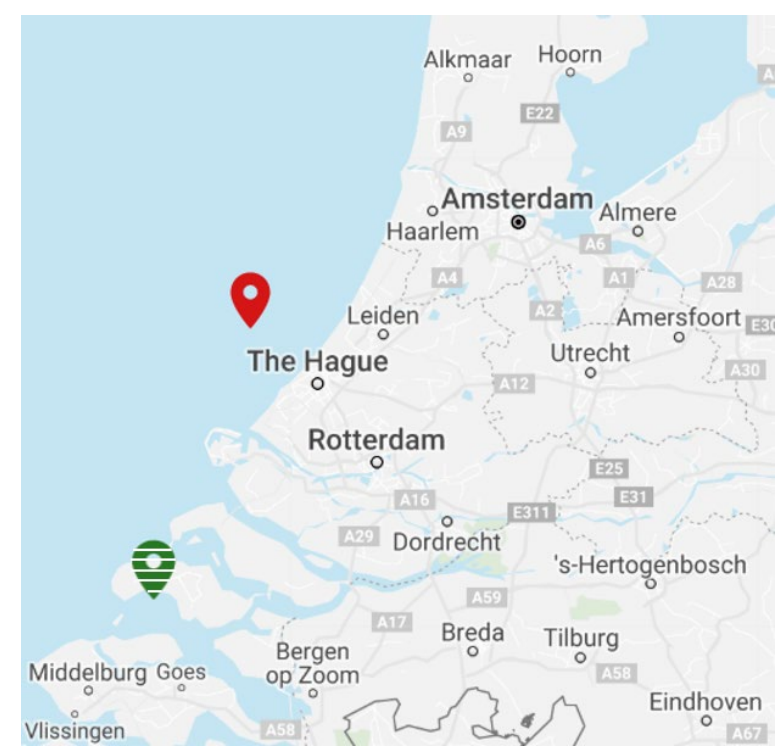

Figure 2 Locations of the test sites. Red pin: Offshore farm (North Sea Innovation lab). Green dashed pin: Inshore farm in the Eastern Scheldt.

\subsection{Flora and fauna on settlement plates from an offshore seaweed farm}

Deployment of settlement plates. 21 settlement plates were deployed in December 2017 at seven positions within the NSIL (Fig. 3). Regular settlement plates named small (S, 14×14cm) were attached to the vertical ropes in the farm at three different depths (1, 3 and 5m, Fig. 3) using tie-wraps. Settlement plates with a different shape named large $(L, 22.5 \times 5 \mathrm{~cm})$ were deployed in triplicates using tie-wraps along the lower horizontal line at $7 \mathrm{~m}$ depth (Fig. 3). Shape was chosen to fit the thick horizontal structure lines of the farm. 


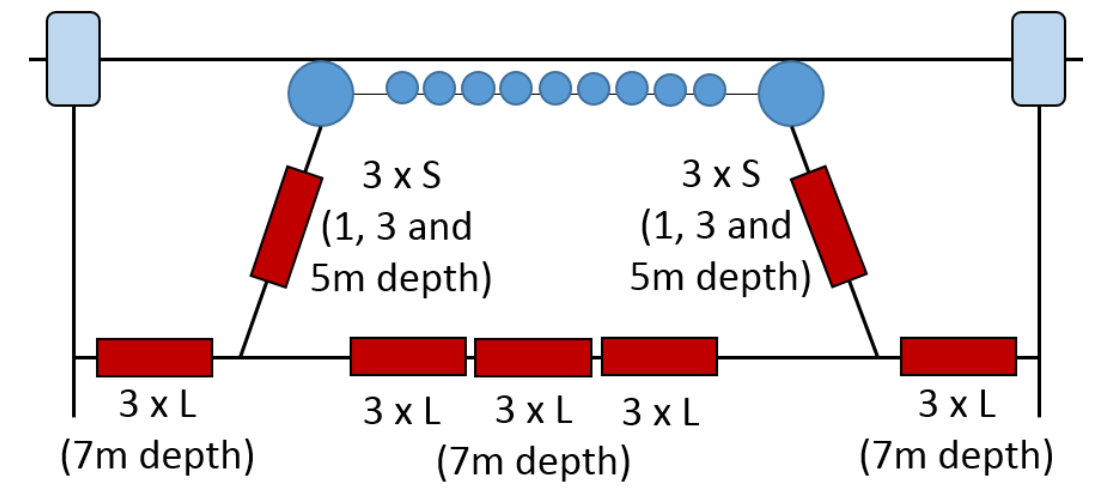

Figure 3 Deployment points of the settlement plates (red boxes) in the North Sea Innovation Lab. $S=$ small settlement plates $(14 \times 14 \mathrm{~cm}), L=$ large settlement plates $(22.5 \times 5 \mathrm{~cm})$. The blue circles and black lines represent buoys and cultivation ropes, respectively.

Collection of settlement plates. In the beginning of June 2018, 3 plates were collected from the western side line ( 1,3 and $5 \mathrm{~m}$ depth), but weather conditions restricted further collection. The rest of the plates were collected 6 weeks later in the middle of July. All material that was used in the process of handling the plates was disinfected before use with $10 \%$ chlorine solution in order to minimize contamination. Settlement plates were cut from the cultivation ropes by divers and directly placed into separate zip lock bags. Close-up photos were taken of each plate and plates were stored in a cool box during the transport to the laboratory where plates were stored at $-80^{\circ} \mathrm{C}$ until being analysed.

\section{3 eDNA analysis of water samples from an inshore seaweed farm}

As a pilot study to test the applicability of water samples for an assessment of mobile fauna, a small number of samples were collected at two positions inside of the SHH farm in August 2018: at the North side and at the outer edge of the South side $(\mathrm{N}=2)$. Additionally, water samples were collected at a control site about $650 \mathrm{~m}$ south east towards the entry to the Schelphoek $(\mathrm{N}=2)$. All material was disinfected before use with $10 \%$ chlorine solution in order to minimize contamination. $1 \mathrm{~L}$ bottles were filled with seawater at approximately $20-30 \mathrm{~cm}$ depth. The water samples were filtered (Nalgene disposable filter units with $\mathrm{CN}$ membrane of $0.8 \mu \mathrm{m}$ pore size, ThermoFisher Scientific, US) and the filters were stored individually in clean dry Eppendorf tubes at $-80^{\circ} \mathrm{C}$ upon DNA extraction.

\subsection{DNA extraction and bioinformatic analysis}

DNA extraction. DNA was extracted from 20 settlement plates and 6 filtered water samples, using different procedures per sample type. The whole DNA extraction process was performed at an extraction laboratory dedicated to processing of environmental DNA (eDNA) samples, available at Wageningen Environmental Research.

Settlement plates were stored at $-80^{\circ} \mathrm{C}$, moved to $-20^{\circ} \mathrm{C}$ the day before DNA extraction and allowed to thaw at room temperature just before DNA extraction. All tissue material was scraped off the surface of both sides of the plate with a stainless steel spatula and transferred to a clean plastic flask. 100ml ethanol was then added to the flask, after which the total content was homogenized using a titanium grinder. Flasks were kept on ice throughout the procedure. After the processing of each sample, the grinder was thoroughly cleaned, submerged in bleach and then rinsed with demineralized water. $8 \mathrm{~g}$ homogenized material was then transferred to a $50 \mathrm{ml}$ tube, and subjected to DNA extraction using the PowerMax Soil Isolation kit (MoBio). All DNA extraction steps were performed on ice. 
Filters from the water sampling were stored in $2 \mathrm{ml}$ tubes at $-80^{\circ} \mathrm{C}$ upon DNA extraction. DNA extraction was performed for each individual filter using the DNeasy Blood \& Tissue Kit (Qiagen) in combination with Qiashredder homogenizer columns (Qiagen). In cases when DNA extracts from multiple filters were available for one sample, these DNA extracts were pooled, resulting in one pooled extract per water sample for further processing in the PCR amplification.

All DNA extracts were then subjected to an extra cleaning step to remove remaining substances that may inhibit PCR amplification. For this purpose, we used the OneStep ${ }^{\text {TM }}$ PCR Inhibitor Removal Kit (Zymo Research).

DNA amplification. DNA barcoding was performed using two different DNA fragments. The first was a fragment located in the V4-section of the $18 \mathrm{~S}$ region of the mitochondrial DNA. Primers for this region were based on Stoeck et al. (2010), amplifying a 270bp fragment of the V4 region of the eukaryote SSU rRNA gene. We adopted their forward primer TAReuk454FWD1 while using a home-made optimized version of their reverse primer TAReukREV3_(TAReukREV3_v1; 5'-ACTKTCGYTCWTGAYYRA-3') to increase amplification across all eukaryote organisms (Glorius et al., in prep). This allows a broad screening of the diversity of all fauna, plants, algae, protists and fungi in the samples. Discriminatory power within these groups is, however, relatively low. Therefore, we also used a second barcoding region, targeting only the faunal groups, and allowing discrimination of faunal taxa at a higher taxonomic resolution (up to species level). This concerns a fragment of the cytochrome oxidase 1 gene (CO1). Primers were based on Leray et al.(2013), amplifying a 300bp fragment. We adopted their reverse primer jgHCO2198, while using an optimized version of forward primer mICOIintF (mICOIintF_v2; 5'GGIACIGGITGRACWGTNTAYCCNCC-3'; Glorius et al., in prep). PCR amplification of both markers was performed using largely the same PCR protocol. Reactions were performed in a $25 \mu$ reaction volume, consisting of $1 U$ Platinum Taq (Fisher Scientific), 1x PCR buffer, $2.5 \mathrm{mM} \mathrm{MgCl} 2,5 \%(\mathrm{~m} / \mathrm{m})$ Trehalose, $200 \mathrm{ng} / \mu \mathrm{l} \mathrm{BSA}, 200 \mu \mathrm{M}$ dNTP and $250 \mu \mathrm{M}$ of each primer. The cycling program was as follows: 2 minutes at $94^{\circ} \mathrm{C}$ followed by 15 cycles of 30 seconds at $94^{\circ} \mathrm{C}, 3$ minutes at $56^{\circ} \mathrm{C}$ reduced by $1^{\circ} \mathrm{C}$ each cycle and 1 minute at $72^{\circ} \mathrm{C}$, followed by 20 additional cycles of 30 seconds at $94^{\circ} \mathrm{C}, 3$ minutes at $42^{\circ} \mathrm{C}$ and 1 minute at $72^{\circ} \mathrm{C}$ and ended by a 10 minutes hold at $72^{\circ} \mathrm{C}$. A negative control that contained no DNA was included to check for contamination during library preparation.

Sequencing. The produced amplicons were sent to Genome Québec (Canada) for high-throughput sequencing. Here, a second PCR reaction was conducted to add sample-specific index barcodes and Illumina adaptor sequences, and the resulting indexed amplicons were then normalized and pooled per marker, before being sequenced in a 250bp paired-end run on a Illumina Miseq flow cell platform.

Data analysis. The raw reads of 300bp length obtained after sequencing were cleaned by removing primer sequences and low quality reads. Taxa with low read numbers $(<5)$ were excluded from the analysis. "Forward" and "reverse" reads were merged to unique sequences which were blasted against the NCBI nucleotide database for identification up to the lowest possible taxonomic level using blastn. The NCBI hits were used for taxonomic classification when the sequence length exceeded 200bp. The initial species identification was accepted when all blast results belonged to the same species. In cases where the blast results contained several species from the same genus, taxa were identified to genus level. When several genera were among the blast results, taxa were not identified.

Based on an existing species list of the Dutch North Sea (Nederlands Soortenregister: https://www.nederlandsesoorten.nl/) the presence or absence of non-native species in the samples was determined. Furthermore, the identified species were visually screened for non-native species. An overview of the divisions was made in Excel 2016 (Microsoft Corporation, Redmond, WA, USA) and multidimensional scaling (MDS) plots of the read data were constructed in R Studio Version 1.1.423 (Boston, USA). 


\section{Results}

\subsection{Biodiversity on settlement plates}

Visual observation from the settlement plates as well as the seaweed cultivation lines indicated that the farming structures were heavily fouled by the blue mussel (Mytilus edulis) and other biofouling organisms (Fig. 4).
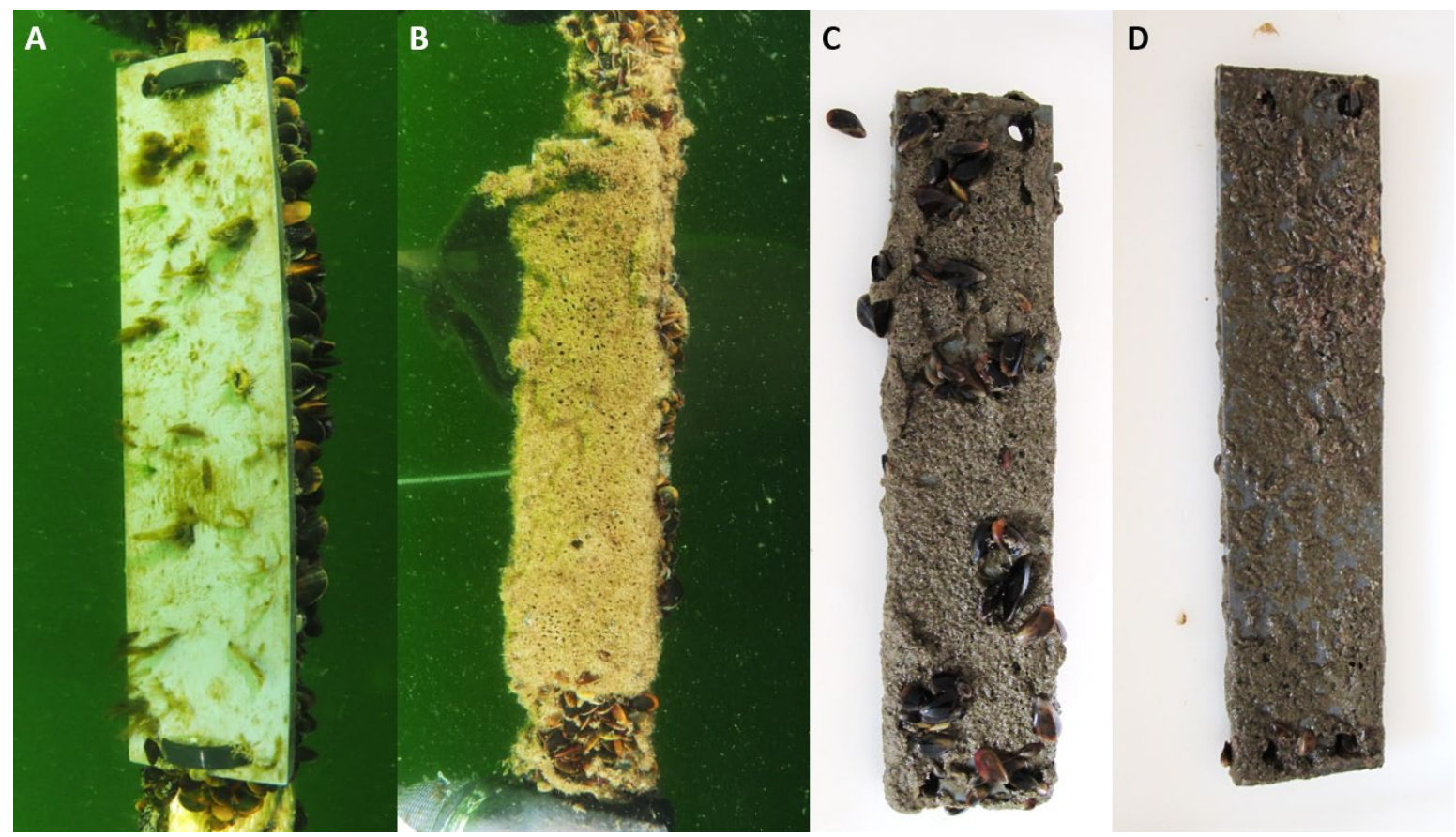

Figure 4 A+B. Settlement plates deployed at the offshore cultivation site (photos by Oscar Bos). $\boldsymbol{C}+\boldsymbol{D}$. Settlement plates collected on the 18/07/2018 from the middle and Eastern lower line, respectively.

In total, 134 different taxa were identified on the settlement plates from the NSIL (Annex Table 1). 71 of the taxa were only detected using the nuclear $18 \mathrm{~S}$ as a marker, 49 of them were only detected by the mitochondrial COI marker and 14 taxa were identified by both markers (Annex Table 1). 69 taxa were determined to species level and 65 to genus level (Annex Table 1, Fig. 5).

Not only the taxa, but also the overall identified divisions varied largely depending on the molecular marker used for the analysis (Fig. 5). Most of the taxa detected by $18 \mathrm{~S}$ belonged to the diatoms $(\mathrm{N}=19)$ and ciliates ( $\mathrm{N}=17$, Fig. 5, blue bars). When the mitochondrial COI was used as a marker (Fig. 5, red bars), the highest amount of taxa were found in the crustaceans $(N=12)$ and bivalves $(N=11)$. Some identified divisions, such as the dinoflagellates, cercozoans or green algae, were only detected by the $18 \mathrm{~S}$ marker whereas others, like the brown algae, sponges and sea anemones, were exclusively detected by COI. Overall (Fig. 5, green bars), the diatoms $(\mathrm{N}=27)$ and crustaceans $(\mathrm{N}=22)$ showed highest taxon numbers, followed by ciliates $(\mathrm{N}=19)$ and bivalves $(\mathrm{N}=16)$. It was expected that mainly sessile fauna could be detected on the settlement plates, but also mobile fauna, such as jellyfishes and planktonic divisions (dinoflagellates, diatoms), were found. 


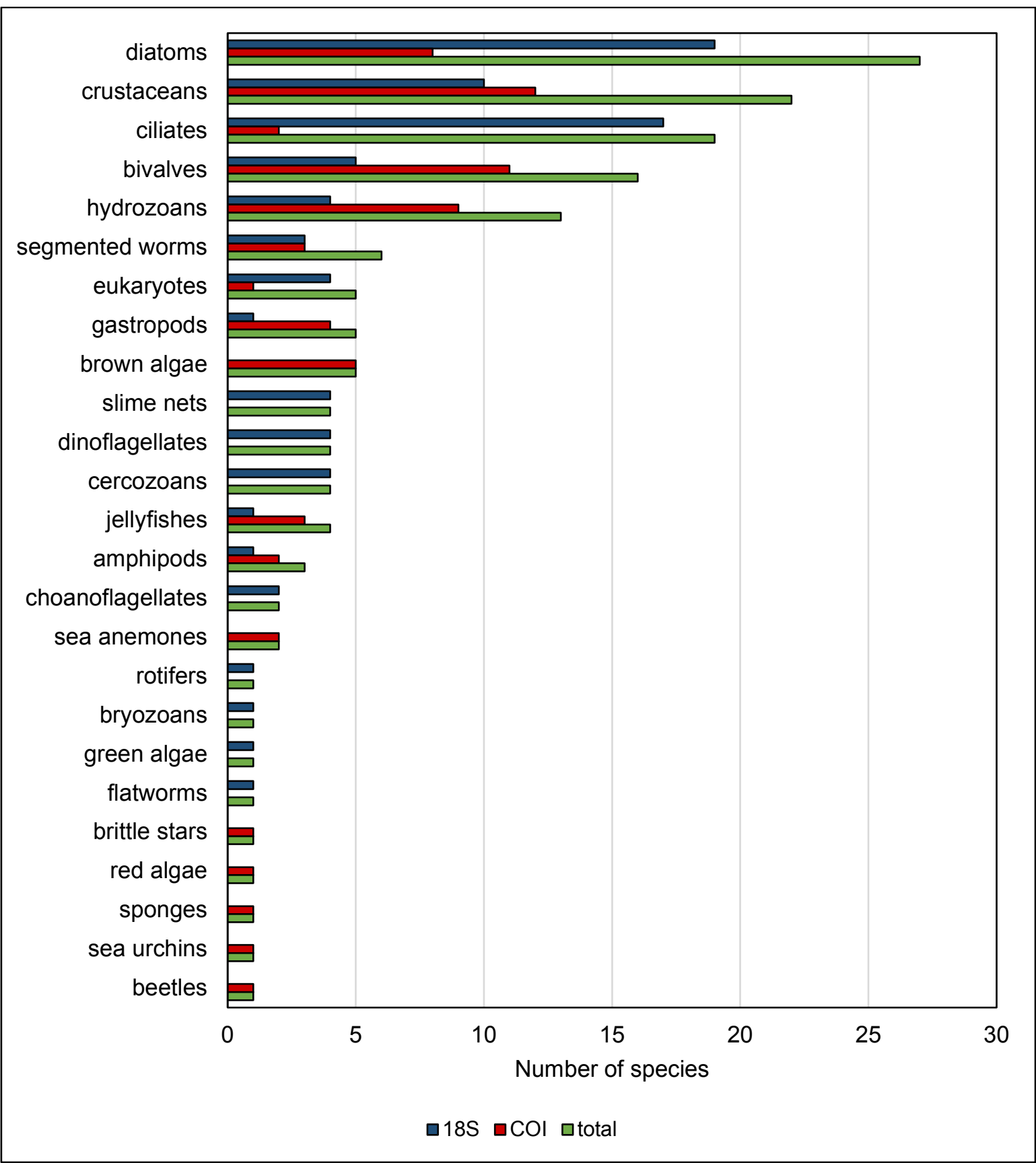

Figure 5 Overview of the divisions found on settlement plates at the offshore cultivation site obtained by comparison with the NCBI database (see also Annex Table 1). Blue bars: taxa detected using 185 as a marker. Red bars: taxa detected using COI as a marker. Green bars: Total number of detected taxa.

The three settlement plates collected 6 weeks earlier from the Western side line showed a slightly different overall species composition than the other plates (light green points, Fig. 6A+B). Besides this, no clear distinction could be made between the different sampling locations since the variation in the species composition within the same sampling locations was very high. 

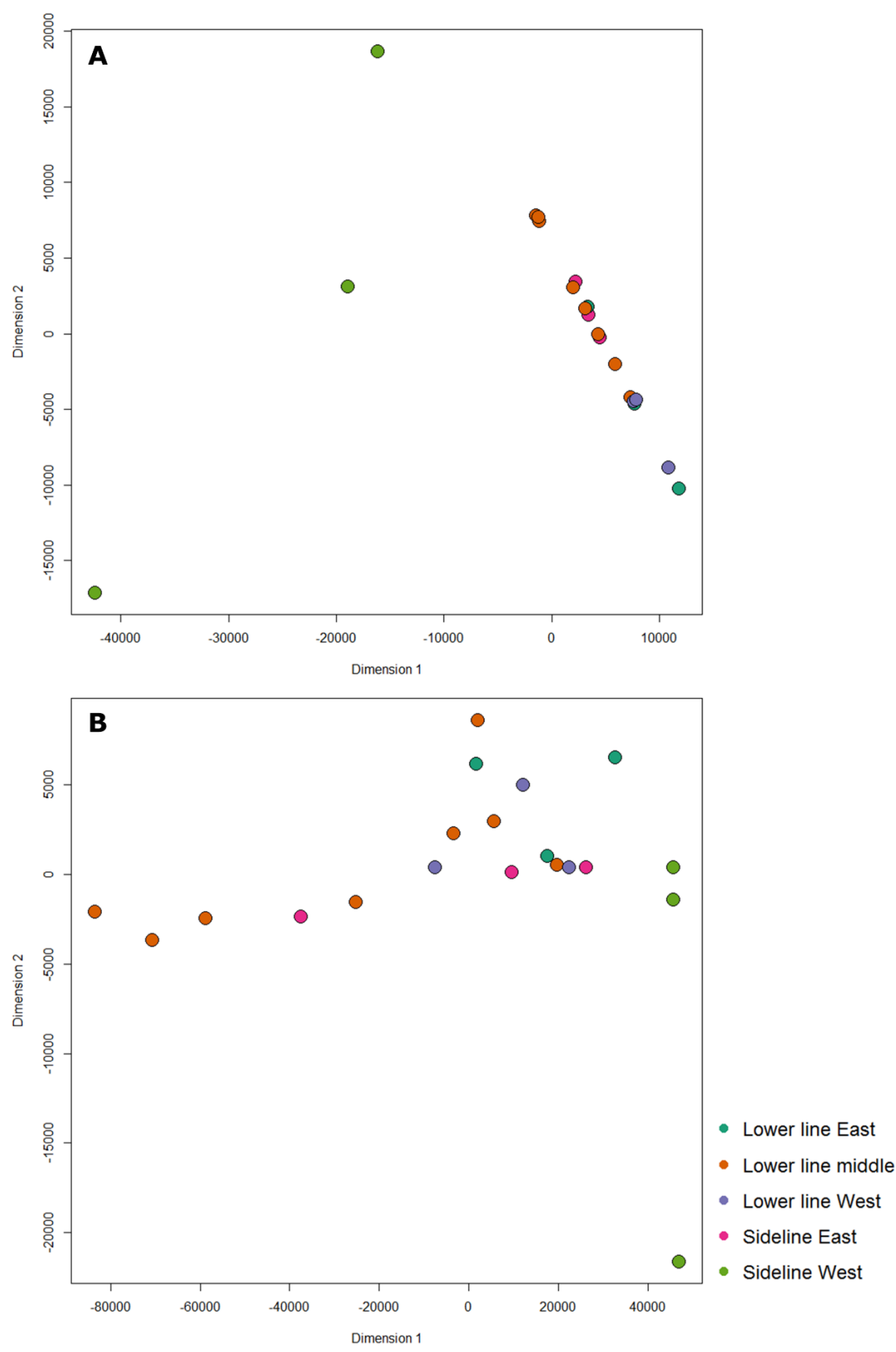

Figure 6 MDS plots of read numbers obtained from the settlement plates at the offshore cultivation site. The proximity of points in the plot indicates the similarity of the species composition detected in different samples. Different colours indicate different positions of the settlement plates within the farm. A. Data obtained using 185 as a marker. B. Data obtained using COI as a marker.

\subsection{Biodiversity in water samples}

In total, 210 different taxa were identified in the water samples from the farm of SHH in the Eastern Scheldt. 148 of them were only detected using the nuclear $18 \mathrm{~S}$ as a marker, 44 of them were only detected by the mitochondrial COI marker and 18 taxa were detected by both markers (Annex Table 2). 93 taxa were determined to genus level, whereas 55 taxa could be identified up to the species level (Annex Table 2, Fig. 7).

Not only the species, but also the detected divisions varied largely depending on the molecular marker (Fig. 7). Most of the taxa detected by $18 \mathrm{~S}$ belonged to the diatoms $(\mathrm{N}=36)$ and dinoflagellates $(\mathrm{N}=26$, Fig. 7, blue bars). When the mitochondrial COI was used as a marker (Fig. 7, red bars), the highest amount of taxa were found in the bivalves $(\mathrm{N}=10)$, the diatoms and the dinoflagellates $(\mathrm{N}=8$, each). Some divisions, such as the slime nets, cercozoans or nematodes, were only detected by the $18 \mathrm{~S}$ marker 
whereas other divisions, like jellyfish, brown algae and sponges, were exclusively detected by COI. Overall, the diatoms $(\mathrm{N}=44)$ and dinoflagellates $(\mathrm{N}=34)$ showed highest taxon numbers in the water samples, followed by ciliates ( $\mathrm{N}=25$, Fig. 7, green bars). The main reason to test this method was the assessment of fish DNA in the seawater. However, no fish species were detected and overall, the amount of mobile species detected in the seawater samples was low. For instance, only one species of jellyfish was found.

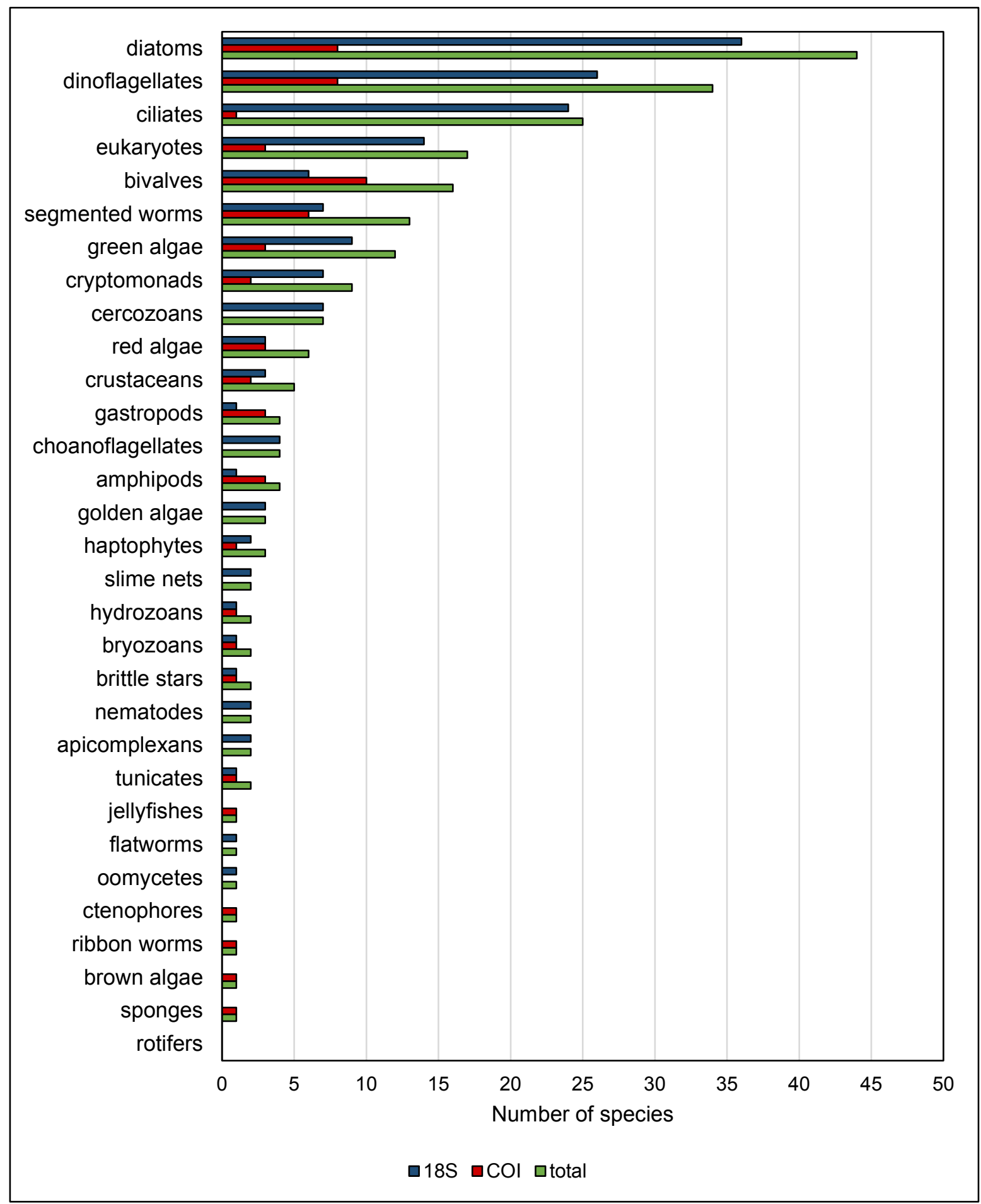

Figure 7 Overview of the divisions found in seawater from the inshore farm in the Eastern Scheldt (see also Annex Table 2). Blue bars: taxa detected using 185 as a marker. Red bars: taxa detected using COI as a marker. Green bars: Total number of detected taxa.

Due to the low number of replicates no further in-depth comparison of the sampling sites was conducted. When interpreting results obtained by eDNA analysis of water samples it has to be kept in mind that the detected species must not necessarily have been present inside the seaweed farm. Water movement 
could also have carried the DNA there and it is thus not sure where the DNA came from. However, slight differences between the samples collected in the farm and the controls outside of the farm were seen.

\subsection{Detection of non-native species}

While an increase in biodiversity by seaweed aquaculture is highly appreciated, the associated risk is that seaweed farms could also serve as a habitat for non-native species which may be attracted by the growing seaweed biomass or the cultivation structures as a substrate. In total, twelve non-native species were identified in this study by comparing the results with the species list of the Dutch North Sea (Nederlands Soortenregister). Four of them are listed among the 100 worst alien species in Europe by DAISIE (Delivering Alien Species Inventories for Europe): Amphibalanus improvisus, Crassostrea gigas, Mnemiopsis leidyi and Styela clava. Two non-native species were found on the settlement plates in the offshore NSIL and 10 non-native species were detected in the water samples from SHH (Table 1).

\section{Table 1}

Non-native taxa detected on settlement plates from the offshore North Sea Innovation lab and in water samples at an inshore seaweed farm. Species information obtained from the species list of the Dutch North Sea (Nederlands Soortenregister). Categories: $2 a=$ exotic species with a reproduction period in the Netherlands of $>100$ years. $2 b=$ exotic species with a reproduction period in the Netherlands of $10-100$ years. $2 c=$ exotic species with a reproduction period in the Netherlands of $<10$ years. $2 d=$ exotic species which is not reproducing in the Netherlands. $3 a=$ insufficient data available, reported for the Netherlands but the current status is unclear. - = not listed.

\begin{tabular}{llll} 
Species & Division & Category & Sampling site \\
Amphibalanus improvisus & crustaceans & 2a & offshore \\
\hline Kappaphycus sp. 'Hainan' & red algae & - & offshore \\
\hline Caprella mutica & amphipods & 2b & inshore \\
\hline Ruditapes philippinarum & bivalves & 2c & inshore \\
\hline Crassostrea gigas & bivalves & 2b & inshore \\
\hline Austrominius modestus & crustaceans & 2b & inshore \\
\hline Mnemiopsis leidyi & ctenophores & 2b & inshore \\
\hline Agardhiella subulata & red algae & 2c & inshore \\
\hline Syllidia armata & segmented worms & 2d & inshore \\
\hline Sabellaria spinulosa & segmented worms & 2d & inshore \\
\hline Styela clava & tunicates & 2b & inshore \\
\hline Botrylloides leachii & tunicates & $3 \mathrm{a}$ & inshore \\
\hline
\end{tabular}

The bay barnacle (Amphibalanus improvisus) was found in the offshore seaweed farm (Fig. 8A). A. improvisus is a dominant fouling organism that has spread from the Atlantic and Gulf Coasts of North America to the European Atlantic and the Mediterranean (WoRMS 2019). Furthermore, the tropical red alga Kappaphycus sp. was detected on one settlement plate from the offshore farm. Kappaphycus is a commercially important red alga which is cultivated for carrageenan production in the Philippines and Indonesia and has been deliberately introduced to other countries, such as Tanzania and several pacific islands, for farming purposes (Luxton and Luxton 1999, Valderrama et al. 2015). While it has been described as an invasive species in India and Hawaii (Conklin and Smith 2005, Kamalakannan et al. 2014), no previous records of this species exist from European waters. It is a tropical species which usually grows in water temperatures of $19.9-29^{\circ} \mathrm{C}$ (Paula and Pereira 2003), and therefore its ability to survive in the North Sea is questionable.

In the inshore farm, the red alga Agardhiella subulata was detected in the water samples from the Eastern Scheldt farm (Fig. 8B). This species was introduced from the North American Atlantic coast to Europe accidentally, probably via introduced shellfish (Petrocelli et al. 2013), and has since spread along the European Atlantic and North Sea coasts. A. subulata has already been found previously in the Eastern 
Scheldt in oyster ponds near Yerseke (Stegenga et al. 2007), and is classified as a recently established species in the Netherlands (Table 1, Wolff 2005).

Among the non-native animals detected at the inshore farm was the Pacific oyster (Crassostrea gigas). The species originated from Japan and Southeast Asia and is currently the most widely farmed oyster species in the world (Helm 2005). After its deliberate introduction to Europe as an alternative for the declining stock of the European oyster Ostrea edulis it has spread extensively and is now found along the entire Dutch coast line (Wolff 2005, Smaal et al. 2009). Another non-native bivalve detected in the water samples was Ruditapes philippinarum, a highly invasive clam species which has been introduced to Europe from the Western Pacific for commercial cultivation (Wolff 2005). Although the numbers of $R$. philippinarum in the Eastern Scheldt have increased rapidly since the first observation in 2008, a previous assessment showed that the species is not likely to alter local habitats or have any other major impact on the ecosystem (Foekema et al. 2014). The barnacle species Austrominius modestus, which is native to Australia and New Zealand, was also found in the inshore seaweed farm (Fig. 8C). Along the European coasts it competes with several native species, such as S. balanoides and Chthamalus spp., and is particularly successful due to its fast growth and tolerance to broad ranges of salinity and temperature (Barnes \& Barnes 1966). Furthermore, two species of segmented worms were detected: Syllidia armata (Fig. 8D) and Sabellaria spinulosa. Both have been introduced to the Eastern Scheldt from France, probably via oysters (Wolff 2005). Styela clava is a tunicate that has been introduced from Asia to the Netherlands in 1970 . The species has since caused problems in mussel farms as a fouling organism on the cultivated species and is also found regularly on boats and other solid structures (Leewis et al. 2006). The second non-native tunicate species detected, Botrylloides leachii, originates from the Asian Pacific, as well. Although it has been reported for the Netherlands previously, its current status of introduction is unclear (category 3a, Table 1). Finally, the Japanese skeleton shrimp, Caprella mutica, was detected in water samples (Fig. 8E). Known in the Netherlands since 1993, the species is often found in large populations on floating objects, such as buoys (Platvoet et al. 1995), making the cultivation structures of seaweed farms a suitable habitat for this species. Since the distribution of $C$. mutica and the native Caprella linearis does not fully overlap, it is expected that both species are able to co-exist in the North Sea (Coolen et al. 2016).

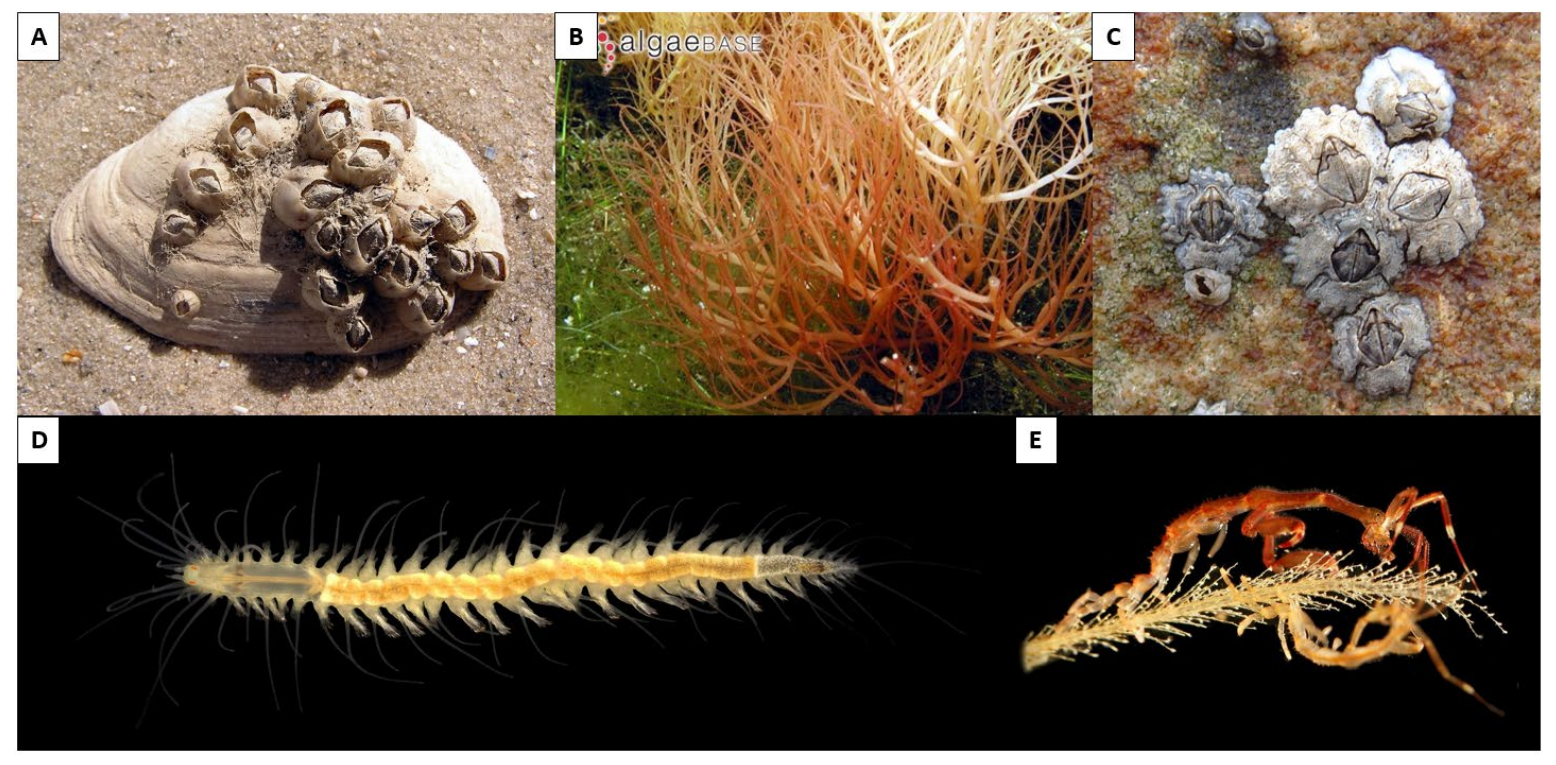

Figure $8 \quad$ Non-native species detected by DNA metabarcoding in Dutch seaweed farms. $\boldsymbol{A}$. Amphibalanus improvisus (photo by Andrew Butko from common.wikimedia.org). B. Agardhiella subulata (photo by Mat Vestjens \& Anne Frijsinger from Algaebase.org). C. Austrominius modestus (photo by Ashley Cottrell from common.wikimedia.org). D. Syllidia armata (photo by Arne Nygren from common. wikimedia.org). E. Caprella mutica (photo by Hans Hillewaert from common.wikimedia.org). 


\section{Conclusions and recommendations}

\subsection{Suitability of DNA metabarcoding for biodiversity analyses in seaweed farms}

In this preliminary study two different sampling methods for DNA metabarcoding analyses were tested for biodiversity assessments in seaweed farms in the North Sea (NSIL) and the Eastern Scheldt (SHH). The analysis of both water samples and settlement plates resulted in an extensive list of detected sequences and a high number of identified taxa (210 and 134 taxa, respectively). Furthermore, a broad taxonomic coverage of 34 different divisions was reached. It is important to emphasize that this study was an exploratory trial of two different ways the technique can be applied and did not serve as a comparison between sites or the different applications of the techniques. Furthermore, because no samples were taken at control sites, and no baseline data is available, whether the detected native and non-native species were already present at the cultivation sites before seaweed was cultivated there or whether they were explicitly attracted by the seaweed farms could not be assessed.

\section{Benefits of DNA metabarcoding}

DNA metabarcoding offers a relatively new approach for biodiversity analyses which allows an automatic and standardized identification of multiple species from bulk or environmental samples and can easily be upscaled without much additional work (Taberlet and Coissac 2012, Leray and Knowlton 2015). It was faster than classical visual identification (Aylagas et al. 2016) and if prices for sequencing continue to decrease in the future, it may even become the cheaper option since fewer work hours are required (Thomsen and Willerslev 2015). While traditional visual species identification based on morphological characteristics can be difficult in cases of cryptic, small or rare species and juveniles (Leray and Knowlton 2015, Pavan-Kumar et al. 2015, Thomsen and Willerslev 2015), all species can be identified by DNA metabarcoding provided that according sequences are available in public databases.

Overall, previous studies where metabarcoding was directly compared to morphological biodiversity assessments have reported promising results. In mesocosm experiments all species present were readily detectable by DNA metabarcoding (Evans et al. 2016) and Aylagas et al. (2016) showed that visual morphological identification and metabarcoding analyses of the same samples of benthic macroinvertebrates produced comparable results. Valentini et al. (2016) even claimed that metabarcoding provides a better detection probability compared to classical traditional surveys, provided that the species relevant for the study are presented in DNA databases.

\section{Limitations and challenges of DNA metabarcoding}

The largest pitfall of DNA metabarcoding is the dependence on reference databases. In order to identify taxa by DNA metabarcoding, sequences are compared to entries in public databases. Consequently, species can only be identified by this technique if sequences of the chosen markers have already been submitted to a public database before. This is especially important to consider when studying exotic species which have not been previously sequenced. Overall, 8424 and 1732 taxonomic units have been detected in this study by COI and $18 \mathrm{~S}$, respectively. Out of these, $12.9 \%$ of the $18 \mathrm{~S}$ sequences could be assigned to genus or species level whereas this was only be possible for $1.4 \%$ of taxa detected by COI. Thus, a large part of the detected taxa remained unidentified. While these values may seem very low, they are comparable to previous literature reports based on the same markers (Cowart et al. 2015, Leray and Knowlton 2015). Although the databases are rapidly growing as sequencing is getting more affordable, large gaps remain, especially in groups that get few research attention (Thomsen and Willerslev 2015). Thus, a considerable investment has still to be made in order to build up comprehensive taxonomic reference libraries for different organism groups (Taberlet and Coissac 2012).

Another crucial point in DNA metabarcoding studies is the choice of the molecular marker. The most frequently used marker in animal studies is the mitochondrial cytochrome oxidase I (COI) which has 
also been adopted by the Consortium for Barcode of Life as a standard for animals specimens (Deagle et al. 2014). As a consequence, COI is often used in animal studies because no other regions can be found in taxonomically verified databases, although it may not always be the best choice due to a lack of conserved regions suitable for primer design (Deagle et al. 2014). Other studies report $18 \mathrm{~S}$ as the best marker for marine macroinvertebrates (Aylagas et al. 2016). The $18 \mathrm{~S}$ region codes for a part of the ribosomal RNA, one of the basic components of all eukaryotic cells, and is therefore highly conserved and less susceptible to mutations than the COI region (Deagle et al. 2014). This is the reason why in our study more than half of the taxa obtained by $18 \mathrm{~S}$ with matches in the NCBI database were identified on a genus level only. On the other hand, using COI as a marker, the species level could be determined for more than $70 \%$ of the identified taxa. This is consistent with a study from Clarke et al. (2017) who reported that while overall taxonomic coverage across zooplankton phyla was similar when using COI and $18 \mathrm{~S}$ ask markers, the taxonomic resolution of the sequences obtained by COI was significantly higher than when using $18 \mathrm{~S}$ as a marker. It is therefore crucial to keep in mind that there is no perfect marker that covers all taxonomic groups (Deagle et al. 2014) and that the choice of a marker introduces a significant bias in the outcome of a study. When focussing on a specific group of organisms it is necessary to perform a literature review in advance of the study in order to determine the most frequently used markers for this target group. In a study like ours, where no specific group is targeted, at least two independent markers should be combined in order to cover a wider taxonomic range (Bernard et al. 2018).

Another limitation of DNA metabarcoding is the PCR step. Samples can contain chemicals that inhibit the activity of Taq polymerase, such as humic acid, which can affect the composition of DNA that is used for sequencing (Thomsen and Willerslev 2015). Besides this, DNA metabarcoding methods also bear a high risk for contamination that can be introduced either in the field or in the lab. There is also the danger of cross-contamination during sampling (Thomsen and Willerslev 2015). However, contamination can be prevented by working carefully and cleaning of all material before use.

DNA metabarcoding analyses are also challenging regarding the definition of the spatial scale of the sample. When settlement plates are used, the material is scraped off and analysed. Thus, it can be assumed that all detected taxa were actually present on the settlement plates, which makes them a reliable tool for the assessment of sessile fauna. However, it also lowers the possibility to detect pelagic species, such as fish. On the same day the water samples were collected in the onshore farm in the Eastern Scheldt, underwater video techniques were applied to investigate the mobile fauna in the farm (Tonk et al. 2019). Horse mackerel (Trachurus trachurus) and big-sand smelt (Aterina boyeri) were observed in the farm by video recordings (Tonk et al. 2019), but they were not detected by DNA metabarcoding, although marker sequences of both species are available on Genbank (NCBI). Furthermore, three jellyfish species were detected by baited cameras (Tonk et al. 2019) but not by DNA metabarcoding, although $18 \mathrm{~S}$ sequences of all three species are available on Genbank (NCBI). Thus, the use of water samples for biodiversity analyses requires further preliminary tests before it can be used for reliable assessments in order to ensure that all species present in the farm can be detected. Furthermore, it is also possible to detect DNA of species in water samples which may not actually be present in a seaweed farm. The origin of the DNA in a seawater sample is entirely unclear and although DNA degrades rapidly, it can still be transported over long distances by currents, water movements or predators (Thomsen and Willerslev 2015).

Finally, another important drawback of DNA barcoding for biodiversity analyses is that the detected organisms cannot be quantified yet. There seems to be a positive correlation between the amount of reads and species biomass but primer efficiency is usually species-specific which prevents a quantification of species within a bulk sample (Elbrecht and Leese 2015). Biodiversity assessment by PCR-based metabarcoding can therefore only be performed on a presence-absence basis.

\section{Detection of non-native species}

Non-native species were detected in samples from both seaweed farms. As mentioned above, it is not possible to determine whether exotic species identified in water samples were actually present in the farm. Water that is coming into the Schelphoek from the Eastern Scheldt can carry-in DNA of organisms from other locations, such as one of the multiple mussel farms in the Eastern Scheldt. In case of the exotic species detected on the settlement plates in the offshore farm, it is more likely that these species 
were actually present at the offshore farm. However, the presence of these exotic species cannot be linked directly back to the seaweed farm as no comparison was made with the surrounding area. These species may already have been in the area before and could just have settled on the farm which provides an additional habitat. $A$ baseline or $\mathrm{t}=0$ measurement would be necessary to assess whether non-native species have actually been introduced as a direct result of the seaweed farm. As this is not possible when a farm is already in operation, a comparison to other structures, such as buoys or wind/oil platform could be useful to assess the role of seaweed farms in attraction of exotic species. Overall, DNA metabarcoding is a good method to screen for the presence or absence of non-native species in seaweed farms. For a quantification of species, however, morphological observations are necessary.

The prospected increasing amount of anthropogenic structures in the North Sea creates new hard substrate habitats for a large number of marine species. Empirical data from these structures are necessary to ensure a sustainable development of Blue Growth in Dutch offshore and coastal regions in the future. Although DNA metabarcoding has a number of limitations, it is a promising and powerful tool for biodiversity assessments if reference databases are expanded continuously and results are interpreted carefully.

\subsection{Recommendation for the use of metabarcoding for biodiversity assessments in seaweed farms}

The results presented in this study show that DNA metabarcoding has a high potential for biodiversity assessments in seaweed farms. Fauna on settlement plates can be readily assessed by DNA metabarcoding, but the inclusion of baseline information $(t=0)$ and/or control sites (pelagic and nearby other hard structures) is crucial for the interpretability and reliability of collected data. For the use of water samples, more preliminary studies are necessary before they can be recommended for biodiversity assessments. For instance, more information is needed on the retention time of DNA in seawater and the distance over which DNA can be transported in the water. Furthermore, dilution experiments could help to define lower detection limits of DNA in seawater samples.

1. Settlement plates should be used for studies on sessile fauna whereas water samples may be more suitable when focussing on mobile fauna.

2. At least two independent markers should be used for metabarcoding studies in order to obtain a broader taxonomic coverage. Previous to the conduction of experiments, literature studies should be performed in order to define the two most promising markers for the groups that are studied.

3. When interpreting results obtained from DNA metabarcoding the bias introduced by the dependence on reference databases needs to be considered. Species can only be identified if the marker sequences are present in databases.

4. Baseline data $(t=0)$ or control samples from other hard structures, such as buoys, or wind/oil platform or even the open ocean are necessary for a reliable interpretation of DNA metabarcoding data.

5. For species quantification, metabarcoding has to be combined with another method. The choice of the second method depends on the scientific question. If fish are targeted in the study, a comparison can be made using video techniques (see Tonk et al. 2019). If sessile invertebrates are addressed, comparisons could be made with classical morphological identification.

6. Contaminations and cross-contaminations during sampling can be avoided by wearing gloves and careful cleaning of all material before use.

7. Due to high spatial inaccuracy water samples should not be used for comparing biodiversity at different positions or depths within a seaweed farm due to the possible long-distance transport of DNA in seawater.

8. In order to further evaluate the use of DNA metabarcoding for biodiversity analyses, a direct comparison with traditional morphological identification is recommended. 


\section{Acknowledgements}

We would like to thank Jasper Veen and Eef Brouwers from the North Sea Innovation lab and Joop Coolen and Oscar Bos who assisted the sampling. Furthermore, we wish to acknowledge Julia Wald, John van Leeuwen and other personnel from Seaweed Harvest Holland for access and assistance at their seaweed farm. We would also like to thank the reviewer Anneke van den Brink for her constructive comments. Next generation sequencing (Illumina) was performed by Génome Québec Inc. (Montreal, Canada). 


\section{Quality Assurance}

Wageningen Marine Research utilises an ISO 9001:2015 certified quality management system. This certificate is valid until 15 December 2021. The organisation has been certified since 27 February 2001. The certification was issued by DNV GL.

Furthermore, the chemical laboratory at IJmuiden has NEN-EN-ISO/IEC 17025:2005 accreditation for test laboratories with number L097. This accreditation is valid until $1^{\text {th }}$ of April 2021 and was first issued on 27 March 1997. Accreditation was granted by the Council for Accreditation. The chemical laboratory at IJmuiden has thus demonstrated its ability to provide valid results according a technically competent manner and to work according to the ISO 17025 standard. The scope (L097) of de accredited analytical methods can be found at the website of the Council for Accreditation (www.rva.nl).

On the basis of this accreditation, the quality characteristic $Q$ is awarded to the results of those components which are incorporated in the scope, provided they comply with all quality requirements. The quality characteristic $Q$ is stated in the tables with the results. If, the quality characteristic $Q$ is not mentioned, the reason why is explained.

The quality of the test methods is ensured in various ways. The accuracy of the analysis is regularly assessed by participation in inter-laboratory performance studies including those organized by QUASIMEME. If no inter-laboratory study is available, a second-level control is performed. In addition, a first-level control is performed for each series of measurements.

In addition to the line controls the following general quality controls are carried out:

- Blank research.

- Recovery.

- Internal standard

- Injection standard.

- Sensitivity.

The above controls are described in Wageningen Marine Research working instruction ISW 2.10.2.105. If desired, information regarding the performance characteristics of the analytical methods is available at the chemical laboratory at IJmuiden.

If the quality cannot be guaranteed, appropriate measures are taken. 


\section{References}

Aldridge, J., van de Molen, J. \& Forster, R. 2012. Wider ecological implications of Macroalgae cultivation.

Aylagas, E., Borja, Á., Irigoien, X. \& Rodríguez-Ezpeleta, N. 2016. Benchmarking DNA Metabarcoding for Biodiversity-Based Monitoring and Assessment. Front. Mar. Sci. 3:1-12.

Bak, U.G., Mols-Mortensen, A. \& Gregersen, O. 2018. Production method and cost of commercial-scale offshore cultivation of kelp in the Faroe Islands using multiple partial harvesting. Algal Res. 33:36-47.

Bartsch, I., Wiencke, C., Bischof, K., Buchholz, C.M., Buck, B.H., Eggert, A., Feuerpfeil, P. et al. 2008. The genus Laminaria sensu lato: recent insights and developments. Eur. J. Phycol. 43:1-86.

Bergman, K.C., Svensson, S. \& Öhman, M.C. 2001. Influence of Algal Farming on Fish Assemblages. Mar. Pollut. Bull. 42:1379-89.

Bernard, M. 2018. Seaweed diseases and pests.

Bernard, M.S., Strittmatter, M., Murúa, P., Heesch, S., Youn Cho, G., Leblanc, C. \& Peters, A.F. 2018. Diversity, biogeography and host specificity of kelp endophytes with a focus on the genera Laminarionema and Laminariocolax (Ectocarpales, Phaeophyceae). Eur. J. Phycol.

Bertocci, I., Araújo, R., Oliveira, P. \& Sousa-Pinto, I. 2015. Potential effects of kelp species on local fisheries. J. Appl. Ecol. 52:1216-26.

Buck, B.H. \& Buchholz, C.M. 2004. The offshore-ring: A new system design for the open ocean aquaculture of macroalgae. J. Appl. Phycol. 16:355-68.

Campbell, I., Macleod, A., Sahlmann, C., Neves, L., Funderud, J., Øverland, M., Hughes, A.D. et al. 2019. The Environmental Risks Associated With the Development of Seaweed Farming in Europe - Prioritizing Key Knowledge Gaps. Front. Mar. Sci. 6:107.

Christie, H., Norderhaug, K.M. \& Fredriksen, S. 2009. Macrophytes as habitat for fauna. Mar. Ecol. Prog. Ser. 396:221-33.

Clarke, L.J., Beard, J.M., Swadling, K.M. \& Deagle, B.E. 2017. Effect of marker choice and thermal cycling protocol on zooplankton DNA metabarcoding studies. Ecol. Evol. 7:873-83.

Conklin, E.J. \& Smith, J.E. 2005. Abundance and spread of the invasive red algae, Kappaphycus spp., in Kane'ohe Bay, Hawai'i and an experimental assessment of management options. Biol. Invasions. 7:1029-39.

Coolen, J.W.P., Lengkeek, W., Degraer, S., Kerckhof, F., Kirkwood, R.J. \& Lindeboom, H.J. 2016. Distribution of the invasive Caprella mutica Schurin, 1935 and native Caprella linearis (Linnaeus, 1767) on artificial hard substrates in the North Sea: Separation by habitat. Aquat. Invasions. 11:437-49.

Cowart, D.A., Pinheiro, M., Mouchel, O., Maguer, M., Grall, J., Miné, J. \& Arnaud-Haond, S. 2015. Metabarcoding is powerful yet still blind: A comparative analysis of morphological and molecular surveys of seagrass communities. PLoS One. 10:1-26.

Dayton, P.K. 1985. Ecology of Kelp Communities. Annu. Rev. Ecol. Syst. 16:215-45.

Deagle, B.E., Jarman, S.N., Coissac, E., Pompanon, F. \& Taberlet, P. 2014. DNA metabarcoding and the cytochrome c oxidase subunit I marker: Not a perfect match. Biol. Lett. 10:2-5.

Elbrecht, V. \& Leese, F. 2015. Can DNA-based ecosystem assessments quantify species abundance? Testing primer bias and biomass-sequence relationships with an innovative metabarcoding protocol. PLoS One. $10: 1-16$.

Evans, N.T., Olds, B.P., Renshaw, M.A., Turner, C.R., Li, Y., Jerde, C.L., Mahon, A.R. et al. 2016. Quantification of mesocosm fish and amphibian species diversity via environmental DNA metabarcoding. Mol. Ecol. Resour. 16:29-41.

Foekema, E.M., Cuperus, J. \& van der Weide, B. 2014. Risk assessment of alien species found in and around the oyster basins of Yerseke.

Heather, J.M. \& Chain, B. 2016. The sequence of sequencers: The history of sequencing DNA. Genomics. 107:1-8.

Hughes, A.D., Black, K.D., Campbell, I., Davidson, K., Kelly, M.S. \& Stanley, M.S. 2012. Does seaweed offer a solution for bioenergy with biological carbon capture and storage? Greenh. Gases Sci. Technol. 2:402-7.

James, P.S.B.R., Krishnamurty, C. \& Rodrigo, J.X.R. 1986. Studies on the fauna associated with the cultured seaweed Gracilaria edulis. Proc. Symp. Coast. Aquac. 4:1176-82.

Jansen, H.M., Van Den Burg, S., Bolman, B., Jak, R.G., Kamermans, P., Poelman, M. \& Stuiver, M. 2016. The 
feasibility of offshore aquaculture and its potential for multi-use in the North Sea. Aquac. Int. 24:73556.

Jørgensen, N.M. \& Christie, H. 2003. Diurnal, horizontal and vertical dispersal of kelp-associated fauna. Hydrobiologia. 503:69-76.

Kamalakannan, B., Jeevamani, J.J.J., Nagendran, N.A., Pandiaraja, D. \& Chandrasekaran, S. 2014. Impact of removal of invasive species Kappaphycus alvarezii from coral reef ecosystem in Gulf of Mannar, India. Curr. Sci. 106:1401-8.

Leblanc, C., Schaal, G., Cosse, A., Destombe, C., Valero, M., Riera, P. \& Potin, P. 2011. Trophic and biotic interactions in Laminaria Digitata beds: Which factors could influence the persistence of marine kelp forests in northern brittany? Cah. Biol. Mar. 52:415-27.

Leray, M. \& Knowlton, N. 2015. DNA barcoding and metabarcoding of standardized samples reveal patterns of marine benthic diversity. Proc. Natl. Acad. Sci. 2014:201424997.

Leray, M., Yang, J.Y., Meyer, C.P., Mills, S.C., Agudelo, N., Ranwez, V., Boehm, J.T. et al. 2013. A new versatile primer set targeting a short fragment of the mitochondrial COI region for metabarcoding metazoan diversity: Application for characterizing coral reef fish gut contents. Front. Zool. 10:1-14.

Lippert, H., Iken, K., Rachor, E. \& Wiencke, C. 2001. Macrofauna associated with macroalgae in the Kongsfjord (Spitsbergen). Polar Biol. 24:512-22.

Loureiro, R., Gachon, C.M.M. \& Rebours, C. 2015. Seaweed cultivation: Potential and challenges of crop domestication at an unprecedented pace. New Phytol. 206:489-92.

Lüning, K. \& Pang, S. 2003. Mass cultivation of seaweeds: current practices and approaches. J. Appl. Phycol. 15:115-9.

Luxton, D.M. \& Luxton, P.M. 1999. Development of commercial Kappaphycus production in the Line Islands, Central Pacific. Hydrobiologia. 398/399:477-86.

Mundy, C.N. 2000. An appraisal of methods used in coral recruitment studies. Coral Reefs. 19:124-31.

Nozawa, Y., Tanaka, K. \& Reimer, J.D. 2011. Reconsideration of the surface structure of settlement plates used in coral recruitment studies. Zool. Stud. 50:53-60.

Nyberg, C.D., Thomsen, M.S. \& Wallentinus, I. 2009. Flora and fauna associated with the introduced red alga Gracilaria vermiculophylla. Eur. J. Phycol. 44:395-403.

Paula, E.J. \& Pereira, R.T.L. 2003. Factors affecting the growth rate of Kappaphycus alvarezii (Doty) Doty ex P. Silva (Rhodophyta, Solieriaceae) in sub-tropical waters of São Paulo State, Brazil. Oxford University Press, Oxford.

Pavan-Kumar, A., Gireesh-Babu, P. \& Lakra, W.S. 2015. DNA Metabarcoding: A New Approach for Rapid Biodiversity Assessment. Cell Sci. Mol. Biol. 2.

Pelletier, D., Leleu, K., Mallet, D., Mou-Tham, G., Hervé, G., Boureau, M. \& Guilpart, N. 2012. Remote highdefinition rotating video enables fast spatial survey of marine underwater macrofauna and habitats. PLoS One. 7:1-13.

Peteiro, C. \& Freire, O. 2013. Epiphytism on blades of the edible kelps Undaria pinnatifida and Saccharina latissima farmed under different abiotic conditions. J. World Aquac. Soc. 44:706-15.

Petrocelli, A., Cecere, E. \& Verlaque, M. 2013. Alien marine macrophytes in transitional water systems: new entries and reappearances in a Mediterranean coastal basin. BioInvasions Rec. 2:177-84.

Potin, P., Bouarab, K., Salaün, J.P., Pohnert, G. \& Kloareg, B. 2002. Biotic interactions of marine algae. Curr.Opin.Plant Biol. 5:308-17.

Rees, H.C., Maddison, B.C., Middleditch, D.J., Patmore, J.R.M. \& Gough, K.C. 2014. The detection of aquatic animal species using environmental DNA - a review of eDNA as a survey tool in ecology. J. Appl. Ecol. 51:1450-9.

Roussel, J.-M., Paillisson, J.-M., Tréguier, A. \& Petit, E. 2015. The downside of eDNA as a survey tool in water bodies. J. Appl. Ecol. 52:823-6.

Slijkerman, D.M.E., Glorius, S.T., Gittenberger ${ }^{1}$, A., Van Der Weide, B.E., Bos, O.G., Rensing ${ }^{1}$, M. \& De Groot $^{2}$, G.A. 2017. Monitoring Groningen Sea Ports; Non-indigenous species and risks from ballast water in Eemshaven and Delfzijl. Executive summary.

Smaal, A.C., Kater, B.J. \& Wijsman, J. 2009. Introduction, establishment and expansion of the Pacific oyster Crassostrea gigas in the Oosterschelde (SW Netherlands). Helgol. Mar. Res. 63:75-83.

Sondak, C.F.A., Ang, P.O., Beardall, J., Bellgrove, A., Boo, S.M., Gerung, G.S., Hepburn, C.D. et al. 2017. Carbon dioxide mitigation potential of seaweed aquaculture beds (SABs). J. Appl. Phycol. 29:2363-73.

Stegenga, H., Karremans, M. \& Simons, J. 2007. Zeewieren van de voormalige oesterputten bij Yerseke. Gorteria Tijdschr. voor Onderz. aan Wilde Flora. 32:125-43.

Steneck, R.S., Graham, M.H., Bourque, B.J., Corbett, D., Erlandson, J.M., Estes, J.A. \& Tegner, M.J. 2002. Kelp forest ecosystems: Biodiversity, stability, resilience and future. Environ. Conserv. 29:436-59. 
Stoeck, T., Bass, D., Nebel, M., Christen, R., Jones, M.D.M., Breiner, H.W. \& Richards, T.A. 2010. Multiple marker parallel tag environmental DNA sequencing reveals a highly complex eukaryotic community in marine anoxic water. Mol. Ecol. 19:21-31.

Taberlet, P. \& Coissac, E. 2012. Towards next-generation biodiversity assessment using DNA metabarcoding - Buscar con Google. 33:2045-50.

Thomsen, P.F. \& Willerslev, E. 2015. Environmental DNA - An emerging tool in conservation for monitoring past and present biodiversity. Biol. Conserv. 183:4-18.

Tonk, L., Bernard, M. \& Jansen, H. 2019. The use of video-techniques for monitoring and quantification of mobile fauna in marine cultivation systems.

Valderrama, D., Cai, J., Hishamunda, N., Ridler, N., Neish, I.C., Hurtado, A.Q., Msuya, F.E. et al. 2015. The Economics of Kappaphycus Seaweed Cultivation in Developing Countries: A Comparative Analysis of Farming Systems. Aquac. Econ. Manag. 19:251-77.

Valentini, A., Taberlet, P., Miaud, C., Civade, R., Herder, J., Thomsen, P.F., Bellemain, E. et al. 2016. Nextgeneration monitoring of aquatic biodiversity using environmental DNA metabarcoding. Mol. Ecol. 25:929-42.

Valero, M., Guillemin, M.-L., Destombe, C., Jacquemin, B., Gachon, C.M.M., Badis, Y., Buschmann, A.H. et al. 2017. Perspectives on domestication research for sustainable seaweed aquaculture. Perspect. Phycol. 4:33-46.

van den Burg, S., Stuiver, M., Veenstra, F., Bikker, P., López Contreras, A., Palstra, A., Broeze, J. et al. n.d. A Triple $P$ review of the feasibility of sustainable offshore seaweed production in the North Sea.

Van denHoek, L.S. \& Bayoumi, E.K. 2018. Evaluating Seaweed as a Source of Protein in the Future of Food Production Worldwide. IOSR J. Pharm. Biol. Sci. 13:30-7.

Walls, A.M., Edwards, M.D., Firth, L.B. \& Johnson, M.P. 2017. Successional changes of epibiont fouling communities of the cultivated kelp Alaria esculenta: predictability and influences. Aquac. Environ. Interact. 9:57-71.

Walls, A.M., Kennedy, R., Fitzgerald, R.D., Blight, A.J., Johnson, M.P. \& Edwards, M.D. 2016. Potential novel habitat created by holdfasts from cultivated Laminaria digitata: Assessing the macroinvertebrate assemblages. Aquac. Environ. Interact. 8:157-69.

Wolff, W.J. 2005. Non-indigenous marine and estuarine species in The Netherlands. Zool. Meded. Leiden. 79:1-116.

Wood, D., Capuzzo, E., Kirby, D., Mooney-mcauley, K. \& Kerrison, P. 2017. UK macroalgae aquaculture: What are the key environmental and licensing considerations? Mar. Policy. 83:29-39.

Zemke-White, W.L. \& Smith, J.E. 2003. Environmental impacts of seaweed farming in the tropics. 


\section{Justification}

Report C 070/19

Project Number: 4318200068

The scientific quality of this report has been peer reviewed by a colleague scientist and a member of the Management Team of Wageningen Marine Research

Approved: $\quad$ Anneke van den Brink

Researcher

Signature:

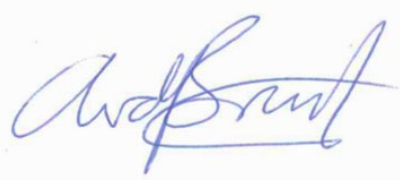

Date:

21 August 2019

$\begin{array}{ll}\text { Approved: } & \text { Jakob Asjes } \\ \text { Manager Integration } \\ \text { Signature: }\end{array}$




\section{Annex}

Table 1

Identified taxa on settlement plates in the offshore farm in the North Sea

\begin{tabular}{|c|c|c|}
\hline Species & Division & Marker \\
\hline Jassa herdmani & amphipods & COI \\
\hline Jassa sp. & amphipods & $18 \mathrm{~S}+\mathrm{COI}$ \\
\hline Agrilus sp. & beetles & COI \\
\hline Abra alba & bivalves & COI \\
\hline Donax sp. & bivalves & $18 \mathrm{~S}$ \\
\hline Donax vittatus & bivalves & COI \\
\hline Ensis sp. & bivalves & $18 \mathrm{~S}+\mathrm{COI}$ \\
\hline Kurtiella sp. & bivalves & COI \\
\hline Lutraria Iutraria & bivalves & $18 \mathrm{~S}$ \\
\hline Mytilus edulis & bivalves & COI \\
\hline Mytilus sp. & bivalves & $18 \mathrm{~S}+\mathrm{COI}$ \\
\hline Mytilus trossulus & bivalves & COI \\
\hline Spisula subtruncata & bivalves & COI \\
\hline Tellimya ferruginosa & bivalves & $18 \mathrm{~S}+\mathrm{COI}$ \\
\hline Ophiura albida & brittle stars & COI \\
\hline Ectocarpus siliculosus & brown algae & COI \\
\hline Ectocarpus sp. & brown algae & COI \\
\hline Hecatonema sp. & brown algae & COI \\
\hline Leathesia sp. & brown algae & COI \\
\hline Petalonia fascia & brown algae & COI \\
\hline Conopeum reticulum & bryozoans & $18 \mathrm{~S}$ \\
\hline Cryothecomonas sp. & cercozoans & $18 \mathrm{~S}$ \\
\hline Massisteria sp. & cercozoans & $18 \mathrm{~S}$ \\
\hline Protaspis sp. & cercozoans & $18 \mathrm{~S}$ \\
\hline Rhabdamoeba marina & cercozoans & $18 \mathrm{~S}$ \\
\hline Acanthoeca spectabilis & choanoflagellates & $18 \mathrm{~S}$ \\
\hline Lagenoeca sp. & choanoflagellates & $18 \mathrm{~S}$ \\
\hline Acineta sp. & ciliates & $18 \mathrm{~S}$ \\
\hline Amphisiella sp. & ciliates & $18 \mathrm{~S}$ \\
\hline Dysteria pectinata & ciliates & $18 \mathrm{~S}$ \\
\hline Ephelota mammillata & ciliates & $18 \mathrm{~S}$ \\
\hline Ephelota plana & ciliates & $18 \mathrm{~S}$ \\
\hline Ephelota sp. & ciliates & $18 \mathrm{~S}+\mathrm{COI}$ \\
\hline Heterohartmannula fangi & ciliates & $18 \mathrm{~S}$ \\
\hline Holosticha sp. & ciliates & $18 \mathrm{~S}$ \\
\hline Hyalophysa sp. & ciliates & $18 \mathrm{~S}$ \\
\hline Hypocoma acinetarum & ciliates & $18 \mathrm{~S}+\mathrm{COI}$ \\
\hline Laboea strobila & ciliates & $18 \mathrm{~S}$ \\
\hline Litonotus sp. & ciliates & $18 \mathrm{~S}$ \\
\hline
\end{tabular}




\begin{tabular}{|c|c|c|}
\hline Loxophyllum sp. & ciliates & $18 \mathrm{~S}$ \\
\hline Paragonostomoides sp. & ciliates & $18 \mathrm{~S}$ \\
\hline Sinistrostrombidium sp. & ciliates & $18 \mathrm{~S}$ \\
\hline Strombidium caudispina & ciliates & $18 \mathrm{~S}$ \\
\hline Strombidium sp. & ciliates & $18 \mathrm{~S}$ \\
\hline Trochilia sp. & ciliates & $18 \mathrm{~S}$ \\
\hline Acartia clausii & crustaceans & $18 \mathrm{~S}$ \\
\hline Ameira scotti & crustaceans & $18 \mathrm{~S}$ \\
\hline Amphibalanus improvisus & crustaceans & COI \\
\hline Balanus crenatus & crustaceans & $18 \mathrm{~S}$ \\
\hline Balanus sp. & crustaceans & $18 \mathrm{~S}+\mathrm{COI}$ \\
\hline Centropages hamatus & crustaceans & COI \\
\hline Centropages typicus & crustaceans & $18 \mathrm{~S}$ \\
\hline Dactylopusia sp. & crustaceans & $18 \mathrm{~S}$ \\
\hline Harpacticus sp. & crustaceans & $18 \mathrm{~S}+\mathrm{COI}$ \\
\hline Hemigrapsus sp. & crustaceans & COI \\
\hline Monopseudocuma gilsoni & crustaceans & COI \\
\hline Paracalanus parvus & crustaceans & $18 \mathrm{~S}+\mathrm{COI}$ \\
\hline Pinnotheres pisum & crustaceans & COI \\
\hline Pseudocalanus sp. & crustaceans & $18 \mathrm{~S}$ \\
\hline Pseudocuma simile & crustaceans & COI \\
\hline Temora longicornis & crustaceans & $18 \mathrm{~S}$ \\
\hline Thia scutellata & crustaceans & COI \\
\hline Thia sp. & crustaceans & $\mathrm{COI}$ \\
\hline Verruca stroemia & crustaceans & $\mathrm{COI}$ \\
\hline Amphora sp. & diatoms & $18 \mathrm{~S}$ \\
\hline Asterionellopsis lenisilicea & diatoms & COI \\
\hline Berkeleya rutilans & diatoms & $18 \mathrm{~S}$ \\
\hline Berkeleya sp. & diatoms & $18 \mathrm{~S}$ \\
\hline Chaetoceros sp. & diatoms & $18 \mathrm{~S}+\mathrm{COI}$ \\
\hline Cocconeis sp. & diatoms & $18 S$ \\
\hline Cylindrotheca sp. & diatoms & $18 \mathrm{~S}$ \\
\hline Grammonema striatula & diatoms & COI \\
\hline Leptocylindrus sp. & diatoms & $18 \mathrm{~S}$ \\
\hline Melosira nummuloides & diatoms & COI \\
\hline Melosira sp. & diatoms & COI \\
\hline Navicula ramosissima & diatoms & COI \\
\hline Navicula sp. & diatoms & $18 \mathrm{~S}$ \\
\hline Nitzschia sp. & diatoms & $18 \mathrm{~S}$ \\
\hline Paralia longispina & diatoms & $18 \mathrm{~S}$ \\
\hline Paralia sulcata & diatoms & $18 \mathrm{~S}$ \\
\hline Psammodictyon sp. & diatoms & $18 \mathrm{~S}$ \\
\hline Pseudogomphonema sp. & diatoms & $18 \mathrm{~S}$ \\
\hline Pseudo-nitzschia delicatissima & diatoms & $\mathrm{COI}$ \\
\hline Pseudo-nitzschia sp. & diatoms & $18 \mathrm{~S}$ \\
\hline Rhizosolenia sp. & diatoms & $18 \mathrm{~S}$ \\
\hline
\end{tabular}




\begin{tabular}{|c|c|c|}
\hline Skeletonema dohrnii & diatoms & $18 \mathrm{~S}$ \\
\hline Tabularia sp. & diatoms & $18 \mathrm{~S}+\mathrm{COI}$ \\
\hline Thalassiosira profunda & diatoms & $18 \mathrm{~S}$ \\
\hline Thalassiosira sp. & diatoms & $18 \mathrm{~S}$ \\
\hline Dissodinium pseudolunula & dinoflagellates & $18 \mathrm{~S}$ \\
\hline Heterocapsa rotundata & dinoflagellates & $18 \mathrm{~S}$ \\
\hline Karlodinium veneficum & dinoflagellates & $18 \mathrm{~S}$ \\
\hline Noctiluca scintillans & dinoflagellates & $18 \mathrm{~S}$ \\
\hline Tripos sp. & dinoflagellates & $18 \mathrm{~S}$ \\
\hline Parvilucifera sp. & eukaryotes & $18 \mathrm{~S}$ \\
\hline Squamamoeba japonica & eukaryotes & COI \\
\hline Telonema subtile & eukaryotes & $18 \mathrm{~S}$ \\
\hline Vannella sp. & eukaryotes & $18 \mathrm{~S}$ \\
\hline Vexillifera sp. & eukaryotes & $18 \mathrm{~S}$ \\
\hline Microstomum sp. & flatworms & $18 \mathrm{~S}$ \\
\hline Euspira nitida & gastropods & COI \\
\hline Peringia sp. & gastropods & COI \\
\hline Peringia ulvae & gastropods & $18 \mathrm{~S}+\mathrm{COI}$ \\
\hline Tritia reticulata & gastropods & COI \\
\hline Tetraselmis sp. & green algae & $18 \mathrm{~S}$ \\
\hline Clytia gracilis & hydrozoans & $18 \mathrm{~S}$ \\
\hline Clytia hemisphaerica & hydrozoans & $18 \mathrm{~S}$ \\
\hline Clytia sp. & hydrozoans & COI \\
\hline Clytia sp. 1 SL-2013 & hydrozoans & COI \\
\hline Ectopleura larynx & hydrozoans & COI \\
\hline Ectopleura sp. & hydrozoans & $18 \mathrm{~S}$ \\
\hline Eucheilota maculata & hydrozoans & $18 \mathrm{~S}+\mathrm{COI}$ \\
\hline Eutima gegenbauri & hydrozoans & COI \\
\hline Hartlaubella gelatinosa & hydrozoans & COI \\
\hline Leuckartiara octona & hydrozoans & COI \\
\hline Lizzia blondina & hydrozoans & COI \\
\hline Obelia bidentata & hydrozoans & COI \\
\hline Aurelia sp. & jellyfishes & COI \\
\hline Chrysaora hysoscella & jellyfishes & COI \\
\hline Cyanea lamarckii & jellyfishes & COI \\
\hline Cyanea sp. & jellyfishes & $18 \mathrm{~S}$ \\
\hline Kappaphycus sp. 'Hainan' & red algae & COI \\
\hline Proales reinhardti & rotifers & $18 \mathrm{~S}$ \\
\hline Metridium sp. & sea anemones & COI \\
\hline Urticina sp. & sea anemones & COI \\
\hline Echinocardium cordatum & sea urchins & COI \\
\hline Arenicola sp. & segmented worms & COI \\
\hline Owenia sp. & segmented worms & $18 \mathrm{~S}$ \\
\hline Pectinaria koreni & segmented worms & $18 \mathrm{~S}+\mathrm{COI}$ \\
\hline Spio sp. & segmented worms & $18 \mathrm{~S}$ \\
\hline Aplanochytrium blankum & slime nets & $18 \mathrm{~S}$ \\
\hline Aplanochytrium sp. & slime nets & $18 \mathrm{~S}$ \\
\hline
\end{tabular}




\begin{tabular}{lll} 
Labyrinthula sp. & slime nets & $18 \mathrm{~S}$ \\
\hline Oblongichytrium sp. & slime nets & $18 \mathrm{~S}$ \\
\hline
\end{tabular}

\section{Table 2}

Identified taxa in water samples at the inshore farm in the Eastern Scheldt

\begin{tabular}{|c|c|c|}
\hline Species & Division & Marker \\
\hline Caprella mutica & amphipods & COI \\
\hline Gammarus locusta & amphipods & COI \\
\hline Jassa sp. & amphipods & $18 \mathrm{~S}+\mathrm{COI}$ \\
\hline Lecudina sp. & apicomplexans & $18 \mathrm{~S}$ \\
\hline Lecudina tuzetae & apicomplexans & $18 S$ \\
\hline Abra alba & bivalves & COI \\
\hline Barnea candida & bivalves & COI \\
\hline Barnea sp. & bivalves & $18 \mathrm{~S}$ \\
\hline Cerastoderma edule & bivalves & $18 \mathrm{~S}+\mathrm{COI}$ \\
\hline Crassostrea gigas & bivalves & COI \\
\hline Donax sp. & bivalves & $18 \mathrm{~S}$ \\
\hline Ensis sp. & bivalves & $18 \mathrm{~S}+\mathrm{COI}$ \\
\hline Mytilus sp. & bivalves & $18 \mathrm{~S}+\mathrm{COI}$ \\
\hline Ruditapes philippinarum & bivalves & COI \\
\hline Scrobicularia plana & bivalves & COI \\
\hline Spisula subtruncata & bivalves & COI \\
\hline Tellimya ferruginosa & bivalves & $18 \mathrm{~S}+\mathrm{COI}$ \\
\hline Ophiothrix fragilis & brittle stars & COI \\
\hline Ophiothrix oerstedii & brittle stars & $18 \mathrm{~S}$ \\
\hline Fucus sp. & brown algae & COI \\
\hline Conopeum reticulum & bryozoans & $18 \mathrm{~S}$ \\
\hline Electra sp. & bryozoans & COI \\
\hline Cryothecomonas aestivalis & cercozoans & $18 \mathrm{~S}$ \\
\hline Cryothecomonas sp. & cercozoans & $18 \mathrm{~S}$ \\
\hline Cyphoderia sp. & cercozoans & $18 \mathrm{~S}$ \\
\hline Mataza sp. & cercozoans & $18 S$ \\
\hline Minorisa sp. & cercozoans & $18 S$ \\
\hline Phagomyxa odontellae & cercozoans & $18 S$ \\
\hline Ventrifissura sp. & cercozoans & $18 \mathrm{~S}$ \\
\hline Bicosta minor & choanoflagellates & $18 \mathrm{~S}$ \\
\hline Bicosta sp. & choanoflagellates & $18 S$ \\
\hline Calliacantha natans & choanoflagellates & $18 S$ \\
\hline Stephanoeca cauliculata & choanoflagellates & $18 \mathrm{~S}$ \\
\hline Acineta tuberosa & ciliates & $18 \mathrm{~S}$ \\
\hline Askenasia sp. & ciliates & $18 \mathrm{~S}$ \\
\hline Cyclotrichium cyclokaryon & ciliates & $18 \mathrm{~S}$ \\
\hline Cyclotrichium sp. & ciliates & $18 \mathrm{~S}$ \\
\hline Halodinium verrucatum & ciliates & $18 \mathrm{~S}$ \\
\hline Hypocoma acinetarum & ciliates & $18 \mathrm{~S}+\mathrm{COI}$ \\
\hline
\end{tabular}




\begin{tabular}{|c|c|c|}
\hline Laackmanniella prolongata & ciliates & $18 \mathrm{~S}$ \\
\hline Lynnella semiglobulosa & ciliates & $18 \mathrm{~S}$ \\
\hline Monodinium sp. & ciliates & $18 \mathrm{~S}$ \\
\hline Parastrombidinopsis sp. & ciliates & $18 \mathrm{~S}$ \\
\hline Pelagostrobilidium paraepacrum & ciliates & $18 \mathrm{~S}$ \\
\hline Pelagostrobilidium sp. & ciliates & $18 \mathrm{~S}$ \\
\hline Plagiocampa sp. & ciliates & $18 \mathrm{~S}$ \\
\hline Pseudovorticella sinensis & ciliates & $18 \mathrm{~S}$ \\
\hline Rhizodomus tagatzi & ciliates & $18 \mathrm{~S}$ \\
\hline Rimostrombidium veniliae & ciliates & $18 \mathrm{~S}$ \\
\hline Sinistrostrombidium sp. & ciliates & $18 \mathrm{~S}$ \\
\hline Strombidinopsis sp. & ciliates & $18 \mathrm{~S}$ \\
\hline Strombidium biarmatum & ciliates & $18 \mathrm{~S}$ \\
\hline Strombidium chlorophilum & ciliates & $18 \mathrm{~S}$ \\
\hline Strombidium sp. & ciliates & $18 \mathrm{~S}$ \\
\hline Tintinnopsis minuta & ciliates & $18 \mathrm{~S}$ \\
\hline Tintinnopsis sp. & ciliates & $18 \mathrm{~S}$ \\
\hline Trichodina sp. & ciliates & $18 \mathrm{~S}$ \\
\hline Austrominius modestus & crustaceans & COI \\
\hline Cyclops kikuchii & crustaceans & COI \\
\hline Herrmannella sp. & crustaceans & $18 \mathrm{~S}$ \\
\hline Oithona davisae & crustaceans & $18 \mathrm{~S}$ \\
\hline Tachidius triangularis & crustaceans & $18 \mathrm{~S}$ \\
\hline Falcomonas daucoides & cryptomonads & $18 \mathrm{~S}$ \\
\hline Hemiselmis andersenii & cryptomonads & COI \\
\hline Hemiselmis cryptochromatica & cryptomonads & $18 \mathrm{~S}$ \\
\hline Hemiselmis sp. & cryptomonads & $18 \mathrm{~S}$ \\
\hline Rhodomonas sp. & cryptomonads & $18 \mathrm{~S}$ \\
\hline Storeatula major & cryptomonads & $18 \mathrm{~S}$ \\
\hline Teleaulax amphioxeia & cryptomonads & $18 \mathrm{~S}+\mathrm{COI}$ \\
\hline Teleaulax sp. & cryptomonads & $18 \mathrm{~S}$ \\
\hline Mnemiopsis leidyi & ctenophores & COI \\
\hline Actinoptychus sp. & diatoms & $18 \mathrm{~S}$ \\
\hline Biddulphia sp. & diatoms & $18 \mathrm{~S}$ \\
\hline Cerataulina pelagica & diatoms & $18 \mathrm{~S}$ \\
\hline Chaetoceros costatus & diatoms & $18 \mathrm{~S}$ \\
\hline Chaetoceros curvisetus & diatoms & $18 \mathrm{~S}$ \\
\hline Chaetoceros debilis & diatoms & $18 \mathrm{~S}$ \\
\hline Chaetoceros elegans & diatoms & $18 \mathrm{~S}$ \\
\hline Chaetoceros lauderi & diatoms & $18 \mathrm{~S}$ \\
\hline Chaetoceros pseudo-curvisetus & diatoms & $18 \mathrm{~S}$ \\
\hline Chaetoceros socialis & diatoms & COI \\
\hline Chaetoceros sp. & diatoms & $18 \mathrm{~S}+\mathrm{COI}$ \\
\hline Cocconeis sp. & diatoms & $18 \mathrm{~S}$ \\
\hline Coscinodiscus sp. & diatoms & $18 \mathrm{~S}$ \\
\hline Cyclotella sp. & diatoms & $18 \mathrm{~S}$ \\
\hline
\end{tabular}




\begin{tabular}{|c|c|c|}
\hline Cylindrotheca sp. & diatoms & $18 \mathrm{~S}$ \\
\hline Ditylum brightwellii & diatoms & COI \\
\hline Ditylum sp. & diatoms & $18 \mathrm{~S}$ \\
\hline Eucampia sp. & diatoms & $18 \mathrm{~S}$ \\
\hline Eucampia zodiacus & diatoms & COI \\
\hline Guinardia flaccida & diatoms & $18 \mathrm{~S}$ \\
\hline Guinardia sp. & diatoms & $18 \mathrm{~S}$ \\
\hline Guinardia striata & diatoms & $18 \mathrm{~S}$ \\
\hline Hemidiscus cuneiformis & diatoms & $18 \mathrm{~S}$ \\
\hline Lauderia sp. & diatoms & $18 S$ \\
\hline Leptocylindrus minimus & diatoms & $18 S$ \\
\hline Leptocylindrus sp. & diatoms & $18 \mathrm{~S}$ \\
\hline Lithodesmium sp. & diatoms & $18 \mathrm{~S}$ \\
\hline Lithodesmium variabile & diatoms & COI \\
\hline Meuniera sp. & diatoms & $18 S$ \\
\hline Minutocellus polymorphus & diatoms & COI \\
\hline Navicula sp. & diatoms & $18 \mathrm{~S}$ \\
\hline Nitzschia longissima & diatoms & $18 S$ \\
\hline Paralia sulcata & diatoms & $18 S$ \\
\hline Plagiolemma sp. & diatoms & $18 \mathrm{~S}$ \\
\hline Pleurosigma planktonicum & diatoms & $18 S$ \\
\hline Pseudo-nitzschia sp. & diatoms & $18 S$ \\
\hline Rhizosolenia sp. & diatoms & $18 \mathrm{~S}$ \\
\hline Skeletonema sp. & diatoms & $18 \mathrm{~S}+\mathrm{COI}$ \\
\hline Synedra fragilaroides & diatoms & $18 S$ \\
\hline Tenuicylindrus belgicus & diatoms & $18 S$ \\
\hline Thalassiosira sp. & diatoms & $18 \mathrm{~S}$ \\
\hline Trieres chinensis & diatoms & COI \\
\hline Adenoides eludens & dinoflagellates & $18 \mathrm{~S}$ \\
\hline Akashiwo sanguinea & dinoflagellates & $18 \mathrm{~S}+\mathrm{COI}$ \\
\hline Amoebophrya sp. & dinoflagellates & $18 \mathrm{~S}$ \\
\hline Amphidinium longum & dinoflagellates & $18 \mathrm{~S}$ \\
\hline Archaeperidinium sp. & dinoflagellates & $18 S$ \\
\hline Blixaea quinquecornis & dinoflagellates & $18 \mathrm{~S}$ \\
\hline Euduboscquella cachoni & dinoflagellates & $18 \mathrm{~S}$ \\
\hline Euduboscquella sp. & dinoflagellates & $18 \mathrm{~S}$ \\
\hline Gonyaulax sp. & dinoflagellates & COI \\
\hline Gymnodinium sp. & dinoflagellates & $18 \mathrm{~S}$ \\
\hline Gyrodinium sp. & dinoflagellates & $18 \mathrm{~S}$ \\
\hline Hematodinium sp. & dinoflagellates & COI \\
\hline Heterocapsa rotundata & dinoflagellates & $18 S$ \\
\hline Heterocapsa sp. & dinoflagellates & $18 \mathrm{~S}$ \\
\hline Lepidodinium chlorophorum & dinoflagellates & COI \\
\hline Lepidodinium sp. & dinoflagellates & $18 \mathrm{~S}$ \\
\hline Margalefidinium polykrikoides & dinoflagellates & COI \\
\hline Margalefidinium sp. & dinoflagellates & COI \\
\hline
\end{tabular}




\begin{tabular}{|c|c|c|}
\hline Noctiluca scintillans & dinoflagellates & $18 \mathrm{~S}$ \\
\hline Paragymnodinium sp. & dinoflagellates & $18 \mathrm{~S}$ \\
\hline Phalacroma sp. & dinoflagellates & $18 \mathrm{~S}$ \\
\hline Polykrikos kofoidii & dinoflagellates & $18 \mathrm{~S}$ \\
\hline Prorocentrum sp. & dinoflagellates & $18 \mathrm{~S}+\mathrm{COI}$ \\
\hline Protoperidinium cf. depressum & dinoflagellates & COI \\
\hline Protoperidinium claudicans & dinoflagellates & $18 \mathrm{~S}$ \\
\hline Protoperidinium monovelum & dinoflagellates & $18 \mathrm{~S}$ \\
\hline Protoperidinium sp. & dinoflagellates & $18 \mathrm{~S}$ \\
\hline Spiniferites belerius & dinoflagellates & $18 S$ \\
\hline Stoeckeria sp. & dinoflagellates & $18 \mathrm{~S}$ \\
\hline Torodinium sp. & dinoflagellates & $18 \mathrm{~S}$ \\
\hline Tripos sp. & dinoflagellates & $18 \mathrm{~S}$ \\
\hline Warnowia sp. & dinoflagellates & $18 S$ \\
\hline Hexamita nelsoni & diplomonads & $18 \mathrm{~S}$ \\
\hline Apedinella radians & eukaryotes & $18 S$ \\
\hline Chattonella subsalsa & eukaryotes & $18 \mathrm{~S}$ \\
\hline Fibrocapsa japonica & eukaryotes & COI \\
\hline Fibrocapsa sp. & eukaryotes & $18 \mathrm{~S}$ \\
\hline Heterosigma akashiwo & eukaryotes & $18 \mathrm{~S}+\mathrm{COI}$ \\
\hline Katablepharis japonica & eukaryotes & $18 \mathrm{~S}$ \\
\hline Leucocryptos marina & eukaryotes & $18 \mathrm{~S}+\mathrm{COI}$ \\
\hline Picomonas judraskeda & eukaryotes & $18 S$ \\
\hline Pirsonia guinardiae & eukaryotes & $18 \mathrm{~S}$ \\
\hline Pirsonia sp. & eukaryotes & $18 \mathrm{~S}$ \\
\hline Pseudobodo sp. & eukaryotes & $18 \mathrm{~S}$ \\
\hline Pseudopedinella elastica & eukaryotes & $18 \mathrm{~S}$ \\
\hline Pterocystis sp. & eukaryotes & $18 \mathrm{~S}$ \\
\hline Telonema sp. & eukaryotes & $18 \mathrm{~S}$ \\
\hline Telonema subtile & eukaryotes & $18 S$ \\
\hline Pholeter gastrophilus & flatworms & $18 \mathrm{~S}$ \\
\hline Peringia ulvae & gastropods & $18 \mathrm{~S}+\mathrm{COI}$ \\
\hline Polycera quadrilineata & gastropods & COI \\
\hline Tergipes tergipes & gastropods & COI \\
\hline Dinobryon sp. & golden algae & $18 \mathrm{~S}$ \\
\hline Paraphysomonas butcheri & golden algae & $18 \mathrm{~S}$ \\
\hline Paraphysomonas sp. & golden algae & $18 \mathrm{~S}$ \\
\hline Bathycoccus prasinos & green algae & $18 \mathrm{~S}+\mathrm{COI}$ \\
\hline Micromonas pusilla & green algae & $18 \mathrm{~S}+\mathrm{COI}$ \\
\hline Micromonas sp. & green algae & $18 \mathrm{~S}$ \\
\hline Ostreococcus sp. & green algae & $18 S$ \\
\hline Pterosperma cristatum & green algae & $18 \mathrm{~S}$ \\
\hline Pycnococcus provasolii & green algae & COI \\
\hline Pyramimonas obovata & green algae & $18 S$ \\
\hline Pyramimonas sp. & green algae & $18 S$ \\
\hline Tetraselmis sp. & green algae & $18 \mathrm{~S}$ \\
\hline Ulva sp. & green algae & $18 S$ \\
\hline
\end{tabular}




\begin{tabular}{|c|c|c|}
\hline Chrysochromulina sp. & haptophytes & $18 \mathrm{~S}$ \\
\hline Haptolina sp. & haptophytes & $18 \mathrm{~S}$ \\
\hline Phaeocystis globosa & haptophytes & COI \\
\hline Eucheilota maculata & hydrozoans & $18 \mathrm{~S}+\mathrm{COI}$ \\
\hline Chrysaora hysoscella & jellyfishes & COI \\
\hline Daptonema sp. & nematodes & $18 \mathrm{~S}$ \\
\hline Viscosia sp. & nematodes & $18 \mathrm{~S}$ \\
\hline Haliphthoros sp. & oomycetes & $18 \mathrm{~S}$ \\
\hline Acrochaetium moniliforme & red algae & COI \\
\hline Agardhiella subulata & red algae & COI \\
\hline Ceramium rubrum & red algae & $18 \mathrm{~S}$ \\
\hline Chondrus sp. & red algae & $18 \mathrm{~S}$ \\
\hline Melanothamnus harveyi & red algae & COI \\
\hline Pyropia sp. & red algae & $18 \mathrm{~S}$ \\
\hline Lineus bilineatus & ribbon worms & COI \\
\hline Alitta succinea & segmented worms & $18 \mathrm{~S}$ \\
\hline Capitella sp. & segmented worms & $18 \mathrm{~S}$ \\
\hline Hediste diversicolor & segmented worms & COI \\
\hline Pectinaria koreni & segmented worms & $18 \mathrm{~S}+\mathrm{COI}$ \\
\hline Polydora cornuta & segmented worms & COI \\
\hline Protodrilus adhaerens & segmented worms & COI \\
\hline Protodrilus sp. & segmented worms & $18 \mathrm{~S}$ \\
\hline Sabellaria spinulosa & segmented worms & COI \\
\hline Spio sp. & segmented worms & $18 \mathrm{~S}$ \\
\hline Streblospio benedicti & segmented worms & COI \\
\hline Syllidia armata & segmented worms & $18 \mathrm{~S}$ \\
\hline Tharyx sp. & segmented worms & $18 \mathrm{~S}$ \\
\hline Aplanochytrium sp. & slime nets & $18 \mathrm{~S}$ \\
\hline Oblongichytrium sp. & slime nets & $18 \mathrm{~S}$ \\
\hline Halichondria sp. & sponges & COI \\
\hline Botrylloides leachii & tunicates & COI \\
\hline Styela clava & tunicates & $18 \mathrm{~S}$ \\
\hline
\end{tabular}


Wageningen Marine Research

T +31(0)317480900

E: marine-research@wur.nl

www.wur.eu/marine-research

Visitors' address

- Ankerpark 271781 AG Den Helder

- Korringaweg 7, 4401 NT Yerseke

- Haringkade 1, 1976 CP IJmuiden
With knowledge, independent scientific research and advice, Wageningen Marine Research substantially contributes to more sustainable and more careful management, use and protection of natural riches in marine, coastal and freshwater areas.

Wageningen Marine Research is part of Wageningen University \& Research. Wageningen University \& Research is the collaboration between Wageningen University and the Wageningen Research Foundation and its mission is: 'To explore the potential for improving the quality of life' 